\title{
Copper(I) Arenethiolates with Intramolecular Coordination and the Formation of Mixed Organo(arenethiolato)copper(I) Aggregates. X-ray Structures of Trimeric $\left[\mathrm{Cu}\left(\mathrm{SC}_{6} \mathrm{H}_{4} \mathrm{NMe}_{2}-2\right)\right]_{3}$, Nonameric $\left[\mathrm{Cu}\left(\mathrm{S}-1-\mathrm{C}_{10} \mathrm{H}_{6} \mathrm{NMe}_{2}-8\right)\right]_{9}$, and Hexanuclear $\left[\mathrm{Cu}_{3}\left(\mathrm{~S}-1-\mathrm{C}_{10} \mathrm{H}_{6} \mathrm{NMe}_{2}-8\right)_{2}\left(\mathrm{C} \equiv \mathrm{C}^{\mathrm{t} B u}\right)\right]_{2}$
}

\author{
Maurits D. Janssen, ${ }^{\dagger}$ Johannes G. Donkervoort, ${ }^{\dagger}$ Sofia B. van Berlekom, ${ }^{\star}$ Anthony L. Spek,,$₫$ \\ David M. Grove, ${ }^{\dagger}$ and Gerard van Koten*, ${ }^{\dagger}$
}

Department of Metal-Mediated Synthesis, Debye Institute, and Department of Crystal and Structural Chemistry, Bijvoet Institute for Biomolecular Research, Utrecht University, Padualaan 8, 3584 CH, Utrecht, The Netherlands

Received December 28, $1995^{\otimes}$

\begin{abstract}
Two new copper(I) arenethiolates with ortho-chelating nitrogen donor atoms $\left[\mathrm{Cu}\left(\mathrm{SC}_{6} \mathrm{H}_{4} \mathrm{NMe}_{2}-2\right)\right]_{3}(\mathbf{5})$ and $[\mathrm{Cu}(\mathrm{S}$ $\left.\left.1-\mathrm{C}_{10} \mathrm{H}_{6} \mathrm{NMe}_{2}-8\right)\right]_{9}(6)$ have been synthesized by reacting $\mathrm{Me}_{3} \mathrm{SiSAr}\left(\mathrm{Ar}=\mathrm{C}_{6} \mathrm{H}_{4} \mathrm{NMe}_{2}-2\right.$ or $\left.1-\mathrm{C}_{10} \mathrm{H}_{6} \mathrm{NMe}_{2}-8\right)$ with copper(I) chloride in a 1:1 molar ratio. Copper(I) arenethiolate $\mathbf{5}$ is a white to pale yellow solid and is trimeric in the solid state as well as in solution. Crystals of $\left[\mathrm{Cu}\left(\mathrm{SC}_{6} \mathrm{H}_{4} \mathrm{NMe}_{2}-2\right)\right]_{3}(\mathbf{5}), \mathrm{C}_{24} \mathrm{H}_{30} \mathrm{Cu}_{3} \mathrm{~N}_{3} \mathrm{~S}_{3}$, are trigonal, space group $R 3$, with $a=b=18.2325(7) \AA, c=6.8410(4) \AA, V=1969.4(2) \AA^{3}, Z=3$, and final $R=0.028$ for 1010 reflections with $I \geq 2.5 \sigma(I)$ and 107 variables. Copper(I) arenethiolate 6 forms dark red crystals and is nonameric in the solid state as well as in solution. Crystals of $\left\{\left[\mathrm{Cu}\left(\mathrm{S}-1-\mathrm{C}_{10} \mathrm{H}_{6} \mathrm{NMe}_{2}-8\right)\right]_{9}\right\}_{2}\left\{\mathrm{C}_{6} \mathrm{H}_{6}\right\}_{10.5}(\mathbf{6}), \mathrm{C}_{279} \mathrm{H}_{279-}$ $\mathrm{Cu}_{18} \mathrm{~N}_{18} \mathrm{~S}_{18}$, are triclinic, space group $P \overline{1}$, with $a=16.081(2) \AA, b=26.650(4) \AA, c=32.747(6) \AA, \alpha=$ $67.320(13)^{\circ}, \beta=76.180(12)^{\circ}, \gamma=81.226(12)^{\circ}, V=12545(4) \AA^{3}, Z=2$, and final $R=0.118$ for 28749 reflections and 1501 variables. Reaction of nonameric 6 with (3,3-dimethylbutynyl)copper results in the formation of the $2: 1$ mixed dimeric hexanuclear organo(arenethiolato)copper aggregate $\left[\mathrm{Cu}_{3}\left(\mathrm{~S}-1-\mathrm{C}_{10} \mathrm{H}_{6} \mathrm{NMe}_{2}-8\right)_{2}\left(\mathrm{C} \equiv \mathrm{C}^{\mathrm{t} B u}\right)\right]_{2}(\mathbf{9})$, $\mathrm{C}_{60} \mathrm{H}_{66} \mathrm{Cu}_{6} \mathrm{~N}_{4} \mathrm{~S}_{4}$, which has been isolated as an air-stable orange solid which is insoluble in most common organic solvents. Crystals of 9 are monoclinic, space group $P 2{ }_{1} / \mathrm{c}$, with $a=11.9839(5) \AA, b=12.9391(8) \AA$, $c=$ $18.9482(7) \AA, \beta=108.326(3)^{\circ}, V=2789.1(2) \AA^{3}, Z=2$, and final $R=0.0314$ for 5110 reflections with $I \geq$ $2.5 \sigma(I)$ and 358 variables. Reaction of 6 with mesitylcopper, $\left[\mathrm{Cu}_{5}\left(\mathrm{C}_{6} \mathrm{H}_{2} \mathrm{Me}_{3}-2,4,6\right)_{5}\right]$, results in the formation of the 1:1 mixed organo(arenethiolato)copper aggregate $\left[\mathrm{Cu}_{2}\left(\mathrm{~S}-1-\mathrm{C}_{10} \mathrm{H}_{6} \mathrm{NMe}_{2}-8\right)\left(\mathrm{C}_{6} \mathrm{H}_{2} \mathrm{Me}_{3}-2,4,6\right)\right]_{n}(\mathbf{1 0})$, which is a yellowish-brown, slightly air-sensitive solid that is soluble in polar and aromatic hydrocarbons. The new mixed aggregates $\mathbf{9}$ and $\mathbf{1 0}$ are thermodynamically and kinetically very stable, and it is found that the overall structure of mixed organo(arenethiolato)copper aggregates such as $\mathbf{9}$ is insensitive to structural changes in the arenethiolate ligand.
\end{abstract}

\section{Introduction}

Copper(I) arenethiolates are well-known in the literature and generally have multinuclear, oligomeric or polymeric structures. ${ }^{1-6}$ Although neutral species $\left[\mathrm{Cu}_{n}(\mathrm{SAr})_{n}\right]$ are the most commonly encountered species, also anionic $\left[\mathrm{Cu}_{n}(\mathrm{SR})_{m}\right]^{n-m}$ clusters with $m>n$ are well documented. ${ }^{6}$ The latter (anionic) species often result when coordinating ligands such as amines or phosphines are absent. ${ }^{1}$

* To whom correspondence should be addressed. E-Mail: vankoten@ xray.chem.ruu.nl.

$\dagger$ Debye Institute.

* Erasmus exchange student from Chalmers University of Technology, Göteborg, Sweden.

$\S$ Bijvoet Institute for Biomolecular Research.

" To whom correspondence pertaining to crystallographic studies should be addressed. E-mail: spea@xray.chem.ruu.nl.

${ }^{\otimes}$ Abstract published in Advance ACS Abstracts, June 15, 1996.

(1) For a review on copper thiolate structures see: Dance, I. G. Polyhedron 1986, 5, 1037-1104.

(2) References for trimeric complexes follow. (a) $\left[\mathrm{Cu}\left(\mathrm{SC}_{6} \mathrm{H}_{4}\{\mathrm{C}(\mathrm{H})\right.\right.$ $\left.\left.\left.\mathrm{MeNMe}_{2}\right\}-2\right)\right]_{3}$ : Knotter, D. M.; van Maanen, H. L.; Grove, D. M.; Spek, A. L.; van Koten, G. Inorg. Chem. 1991, 30, 3309-3317. (b) $\left[\left\{(R)-(S)-\left(\eta^{5}-\mathrm{C}_{5} \mathrm{H}_{5}\right) \mathrm{Fe}\left(\eta^{5}-\mathrm{C}_{5} \mathrm{H}_{3}\left(1-\mathrm{PPh}_{2}\right)\left(2-\mathrm{CH}\left(\mathrm{CH}_{3}\right) \mathrm{S}\right)\right)\right\} \mathrm{Cu}\right]_{3}:$ Togni, A.; Rihs, G.; Blumer, R. E. Organometallics 1992, 11, 613-621.

(3) Tetrameric $\left[\mathrm{Cu}\left\{\mathrm{SC}_{6} \mathrm{H}_{4}\left(\mathrm{CH}_{2} \mathrm{~N}(\mathrm{Me}) \mathrm{CH}_{2} \mathrm{CH}_{2} \mathrm{OMe}\right)-2\right\}\right]_{4}$ : Knotter, D. M.; Janssen, M. D.; Grove, D. M.; Smeets, W. J. J.; Horn, E.; Spek, A. L.; van Koten, G. Inorg. Chem. 1991, 30, 4361-4366.
Recently we reported copper(I) arenethiolates with orthochelating nitrogen donor substituents that, like those with bulky ortho substituents, have well-defined structures both in solution and in the solid state. In general, copper(I) arenethiolates can exist in various aggregation states and complexes with trimeric, ${ }^{2}$ tetrameric, ${ }^{3}$ hexameric, ${ }^{4}$ or dodecameric ${ }^{5}$ aggregate structures have been reported. In the presence of amines or phosphines which can function as auxiliary donor ligands, such aggregates can break down to monomeric or dimeric structures. ${ }^{6}$ So far, copper arenethiolates with intramolecularly coordinating substituents have been encountered only as neutral species $[\mathrm{Cu}-$ (SAr)] which form higher aggregates with well-defined structures. $^{2 \mathrm{a}, 3}$ In Chart 1 some representative examples of such aggregates are shown, and these all have discrete structures as a result of intramolecular $S, N$ - and $S, P$-chelate coordination.

(4) References for hexameric complexes follow. (a) (CuSpy)6: (a) Kitagawa, S.; Munakata, M.; Shimono, H.; Matsuyama, S.; Masuda, H. J. Chem. Soc., Dalton Trans. 1990, 2105-2109. (b) (CuSdmpymt)6: Castro, R.; Durán, M. L.; García-Vázquez, J. A.; Romero, J.; Sousa, A.; Castellano, E. E.; Zukerman-Schpector, J. J. Chem. Soc., Dalton Trans. 1992, 2559-2563. (c) (CuSQuin-2) 6 : Kitagawa, S.; Kawata, S.; Nozaka, Y.; Munakata, M. J. Chem. Soc., Dalton Trans. 1993, 1399-1404. (d) (CuSpySiMe $3-3)_{6}$ : Block, E.; Gernon, M.; Kang, H.; Zubieta, J. Angew. Chem. 1988, 100, 1389-1391.

(5) Dodecameric $\left(\mathrm{CuSC}_{6} \mathrm{H}_{4} \mathrm{SiMe}_{3}-2\right)_{12}$ : Block, E.; Gernon, M.; Kang, H.; Ofori-Okai, G.; Zubieta, J. Inorg. Chem. 1989, 28, 1263-1271. 
Chart 1. Examples of Intramolecularly Coordinated Copper(I) Arenethiolates: $\left[\mathrm{Cu}\left\{\mathrm{SC}_{6} \mathrm{H}_{4}\left(\mathrm{CH}(\mathrm{R}) \mathrm{NMe}_{2}\right)-2\right\}\right]_{3}(\mathrm{R}$ $=\mathrm{H}(\mathbf{1 a}), \mathrm{Me}(\mathbf{1 b})) ;{ }^{2 \mathrm{a}}\left[\mathrm{CpFe}\left(\eta^{5}-\mathrm{C}_{5} \mathrm{H}_{3}(\mathrm{CH}(\mathrm{Me}) \mathrm{SCu})\left(\mathrm{PPh}_{2^{-}}\right.\right.\right.$ 2)) $]_{3}(2) ; 2 \mathrm{~b}\left[\mathrm{Cu}\left\{\mathrm{SC}_{6} \mathrm{H}_{4}\left(\mathrm{CH}(\mathrm{R}) \mathrm{N}(\mathrm{Me}) \mathrm{CH}_{2} \mathrm{CH}_{2} \mathrm{OMe}\right)-2\right\}\right]_{4}(\mathrm{R}$ $=\mathrm{H}(\mathbf{3 a}), \mathrm{Me}(\mathbf{3 b})) ;{ }^{3}\left[\mathrm{Cu}\left\{\mathrm{SC}_{5} \mathrm{H}_{4} \mathrm{~N}\right\}\right]_{6}(\mathbf{4})^{4 \mathrm{a}}$

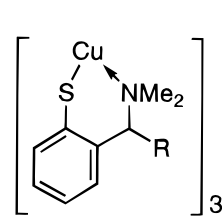

1a: $R=H$ 1b: $R=M e$

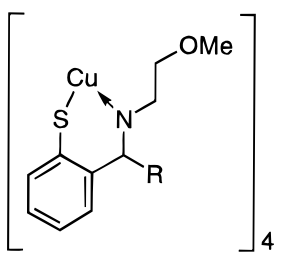

3a: $R=H$

3b: $R=M e$
2

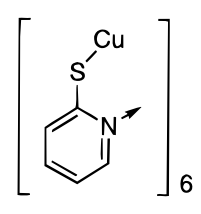

4

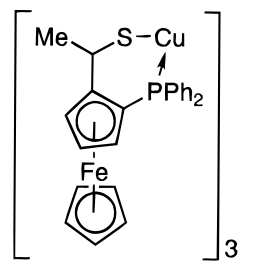

We are using the arenethiolate anion for the development of heterocuprate species of general composition $\left[\mathrm{R}^{\mathrm{r}} \mathrm{R}^{\mathrm{t}} \mathrm{Cu}\right] \mathrm{M}(\mathrm{M}=$ $\mathrm{MgX}, \mathrm{Li}$ ) in which $\mathrm{R}^{\mathrm{t}}$ is a transferable organic group, e.g. alkyl or aryl, and $\mathrm{R}^{\mathrm{r}}$ is a nontransferable arenethiolate group. Such species, which can be formed by a metathesis reaction of the copper arenethiolate and an organometallic reagent $\mathrm{RMgX}$ or $\mathrm{RLi}^{7}$ find wide application in organic synthesis for the selective formation of new $\mathrm{C}-\mathrm{R}^{\mathrm{t}}$ bonds. ${ }^{8}$ The nontransferable group present in these reagents ensures an efficient use of the often valuable $\mathrm{R}^{\mathrm{t}}$ group and when $\mathrm{R}^{\mathrm{r}}$ contains a chiral grouping (e.g., $\mathbf{1 b}$ and $\mathbf{3 b}$ ) it is a potential source of stereochemical information to effect stereoselective $\mathrm{C}-\mathrm{C}$ bond formation. ${ }^{9,10}$

In many cases, reactions that commonly require the stoichiometric use of copper salts can be converted into catalytic reactions when copper arenethiolate catalysts such as $\mathbf{1}$ and $\mathbf{3}$

(6) References for complexes without intramolecular coordination follow (a) $\left(\mathrm{HB}\left(3,5-{ }^{\mathrm{i}} \mathrm{Pr}_{2} \mathrm{pz}\right)_{3}\right) \mathrm{Cu}\left(\mathrm{SC}_{6} \mathrm{~F}_{5}\right)$ : Kitajima, N.; Fujisawa, K.; Tanaka, M.; Moro-oka, Y. J. Am. Chem. Soc. 1992, 114, 9232-9233. (b) $\left[\left(\text { py) } \mathrm{Cu}_{4}\left(\mathrm{C}_{3} \mathrm{H}_{4} \mathrm{NS}_{2}\right)_{4}\right]_{n}\right.$ : Fackler, J. P.; López, C. A.; Staples, R. J.; Wang, S.; Winpenny, R. E. P.; Lattimer, R. P. J. Chem. Soc., Chem. Commun.. 1992, 146-148. (c) $\left[\mathrm{Cu}_{4}\left(\mathrm{SSi}\left(\mathrm{O}^{t} \mathrm{Bu}\right)_{3}\right)_{4}\right]$ : Becker, B.; Wojnowski, W.; Peters, K.; Peters, E.-M.; von Schnering, H. G. Polyhedron 1990, 9, 1659-1666. (d) $\left[\left(\mathrm{Ph}_{3} \mathrm{P}\right)_{4} \mathrm{Cu}_{4}(\mathrm{SPh})_{4}\right]$ : Dance, I. G.; Scudder, M. L.; Fitzpatrick, L. J. Inorg. Chem. 1985, 24, 25472550. (e) $\left[\left(\mathrm{Ph}_{3} \mathrm{P}\right)_{4} \mathrm{Cu}_{2}(\mathrm{SPh})_{2}\right]$ : Dance, I. G.; Guerney, P. J.; Rae, A. D.; Scudder, M. L. Inorg. Chem. 1983, 22, 2883-2887. (f) $\left[\mathrm{Ph}_{4} \mathrm{P}\right]_{2}{ }^{+}\left[\mathrm{Cu}_{4}\left(o-\left(\mathrm{SCH}_{2}\right)_{2} \mathrm{C}_{6} \mathrm{H}_{4}\right)_{3}\right]^{2-}$ : Nicholson, J. R.; Abrahams, I. L.; Clegg, W.; Garner, C. D. Inorg. Chem. 1985, 24, 1092-1096. (g) $\left[\mathrm{Ph}_{4} \mathrm{P}\right]_{4}+\left[\mathrm{Cu}_{8}\left(\mathrm{~S}_{2} \mathrm{C}_{4} \mathrm{O}_{2}\right)_{6}\right]^{4-}$ and $\left[{ }^{\mathrm{n}} \mathrm{Bu}_{4} \mathrm{~N}\right]_{4}{ }^{+}\left[\mathrm{Cu}_{8}\left(\mathrm{~S}_{2} \mathrm{CC}\left(\mathrm{COOC}_{2}-\right.\right.\right.$ $\left.\left.\left.\mathrm{H}_{5}\right)_{2}\right)_{6}\right]^{4-}$ : Hollander, F. J.; Coucouvanis, D. J. Am. Chem. Soc. 1977, 99, 6268-6279. (h) $\left[\mathrm{Et}_{4} \mathrm{~N}\right]^{+}\left[\mathrm{Cu}_{5}\left(\mu^{2}-\mathrm{S}{ }^{t} \mathrm{Bu}\right)_{6}\right]^{-}$: Dance, I. G. J. Chem. Soc., Chem. Commun.. 1976, 68-69. (i) $\left[\mathrm{Me}_{4} \mathrm{~N}_{2}{ }_{2}^{+}\left[\mathrm{Cu}_{4}\left(\mu^{2}-\mathrm{SPh}\right)_{6}\right]^{2-}\right.$ : Dance, I. G.; Calabrese, J. C. Inorg. Chim. Acta 1976, 19, L41-L42. (j) $\left[\mathrm{Me}_{4} \mathrm{~N}\right]_{2}{ }^{+}\left[\mathrm{Cu}_{4}(\mathrm{SMe})_{6}\right]^{2-}$ : Dance, I. G.; Bowmaker, G. A.; Clark, G. R.; Seadon, J. K. Polyhedron 1983, 2, 1031-1043.

(7) Gilman, H.; Straley, J. M. Recl. Trav. Chim. Pays-Bas 1936, 55, 821834.

(8) (a) Lipshutz, B. H. Synthesis 1987, 325-341. (b) Posner, G. H. An Introduction to Synthesis Using Organocopper Reagents; Wiley, New York, 1980. (c) Normant, J. F. Synthesis 1972, 63-80.

(9) 1,4-Addition: (a) Lambert, F.; Knotter, D. M.; Janssen, M. D.; van Klaveren, M.; Boersma, J.; van Koten, G. Tetrahedron: Asymmetry 1991, 2, 1097-1100. (b) van Klaveren, M.; Lambert, F.; Eijkelkamp, D. J. F. M.; Grove, D. M.; van Koten, G. Tetrahedron Lett. 1994, 35, 6135-6138. 1,6-Addition: (c) Haubrich, A.; van Klaveren, M.; van Koten, G.; Handke, G.; Krause, N. J. Org. Chem. 1993, 58, 58495852 . are used. Mechanistic studies have indicated that the geometric properties of the organic backbone connecting the anionic $S$ donor atom to the tertiary amine donor group determines to a large extent the selectivity in these reactions. ${ }^{9,10}$ For this reason we are interested in the copper arenethiolates $\mathbf{5}$ and $\mathbf{6}$ and have studied their structure in the solid state and in solution as well as their catalytic reactivity. ${ }^{9 \mathrm{~b}, 10 \mathrm{a}}$

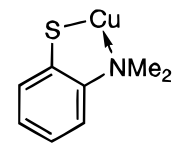

5

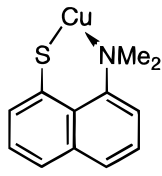

6
Copper(I) arenethiolate $\mathbf{6}$ is similar to complexes $\mathbf{1}$ and $\mathbf{3}$ depicted in Chart 1 in that it contains a six-membered chelate ring formed by $S, N$-coordination of the ligand to a metal center. However, an obvious difference between $\mathbf{6}$ and, for example, $\mathbf{1}$ is the rigid 1,8-disubstituted naphthalene backbone in the former; i.e., the sulfur and nitrogen atoms have a stereochemically fixed mutual orientation. Furthermore, the aromatic amine donor in 6 is expected to have a lower Lewis basicity than the amine donor in benzylic amines $\mathbf{1}$ and $\mathbf{3}$. These chemical and structural features prompted us to study the synthesis of the novel copper(I) arenethiolate $\mathbf{5}$, as in this case the five-membered chelate ring is probably energetically more favorable than the six-membered rings present in complexes $\mathbf{1}, \mathbf{2}, \mathbf{3}$, and $\mathbf{6}$.

A further objective of our study of copper(I) arenethiolates with intramolecular coordination is to understand how these complexes form aggregates with organometallic reagents and substrates to produce the kinetic key intermediate(s) in $\mathrm{Cu}(\mathrm{SAr})$ catalyzed group transfer reactions. ${ }^{9,10}$ We have already reported that the reaction of $\left[\mathrm{Cu}\left(\mathrm{SC}_{6} \mathrm{H}_{4} \mathrm{CH}(\mathrm{R}) \mathrm{NMe}_{2}-2\right)\right]_{3}(\mathrm{R}=\mathrm{H}(\mathbf{1 a})$, $\mathrm{Me}(\mathbf{1 b}))^{2 \mathrm{a}}$ with organolithium or organocopper reagents leads to the selective (i.e., quantitative) formation of unprecedented mixed alkynyl(arenethiolato)- and mesityl(arenethiolato)copper(I) aggregates $\left[\mathrm{Cu}_{3}(\mathrm{SAr})_{2}\left(\mathrm{C} \equiv \mathrm{C}^{\mathrm{t}} \mathrm{Bu}\right)\right]_{2}(7)^{11}$ and $\left[\mathrm{Cu}_{2^{-}}\right.$ $(\mathrm{SAr})(\mathrm{Mes})]_{2}(\mathbf{8}),{ }^{12}$ respectively (Scheme 1$)$.

This paper deals with the synthesis and structural characterization of two novel copper(I) arenethiolates (i.e. trimeric 5 and nonameric 6) having $\mathrm{Cu}-\mathrm{N}$ intramolecular coordination and additionally with a study of the reactivity of $\mathbf{5}$ and $\mathbf{6}$ toward pure organocopper aggregates. It is shown that mixed 2:4 and 2:2 organo(arenethiolato)copper(I) aggregates are formed in reactions of the nonameric copper(I) arenethiolate $[\mathrm{Cu}(\mathrm{S}-1-$ $\left.\left.\mathrm{C}_{10} \mathrm{H}_{6} \mathrm{NMe}_{2}-8\right)\right]_{9}$ (6) with the pure organocopper(I) species $\left[\mathrm{CuC} \equiv \mathrm{C}^{\mathrm{t}} \mathrm{Bu}\right]_{8}$ and $\left[\mathrm{Cu}\left(\mathrm{C}_{6} \mathrm{H}_{2} \mathrm{Me}_{3}-2,4,6\right)\right]_{5}$.

\section{Experimental Section}

Syntheses were carried out using standard Schlenk techniques under an atmosphere of dry, oxygen-free nitrogen. Toluene, benzene, hexane, and pentane were carefully dried and distilled from sodium benzophenone ketyl prior to use. $\mathrm{CH}_{2} \mathrm{Cl}_{2}$ was distilled from $\mathrm{CaH}_{2}$. Pyridine was dried on molecular sieves $(4 \AA)$ and distilled prior to use. ${ }^{1} \mathrm{H}$ and ${ }^{13} \mathrm{C}$ NMR spectra were recorded on a Bruker AC200 or a Bruker AC300 spectrometer. Direct-inlet mass analyses (EI) were carried out using a UNICAM AUTOMASS mass spectrometer. Thermogravimetric analy-

(10) (a) van Klaveren, M.; Persson, E. S. M.; Grove, D. M.; Bäckvall, J.-E.; van Koten, G. Tetrahedron Lett. 1994, 35, 5931-5934. (b) Persson, E. S. M.; van Klaveren, M.; Bäckvall, J.-E.; van Koten, G. Chem. Eur. J. 1995, 1, 351.

(11) $\left[\mathrm{Cu}_{3}(\mathrm{SAr})_{2}\left(\mathrm{C} \equiv \mathrm{C}^{\mathrm{t} B u}\right)\right]_{2}$ : Knotter, D. M.; Spek, A. L.; Grove, D. M.; van Koten, G. Organometallics 1992, 11, 4083-4090.

(12) $\left[\mathrm{Cu}_{4}(\mathrm{Mes})_{4}\right]\left[\mathrm{Mg}(\mathrm{SAr})_{2}\right]_{2},\left[\mathrm{Cu}_{4}(\mathrm{SAr})_{2}(\mathrm{Mes})_{2}\right]$, and $\left[\mathrm{Cu}_{3}(\mathrm{SAr})_{2}(\mathrm{Mes})-\right.$ $\left(\mathrm{PPh}_{3}\right)$ ]: Knotter, D. M.; Grove, D. M.; Smeets, W. J. J.; Spek, A. L.; van Koten, G. J. Am. Chem. Soc. 1992, 114, 3400-3410. 
Scheme 1. Formation of Mixed Organo(arenethiolato)copper Aggregates $\mathbf{7}$ and $\mathbf{8}$
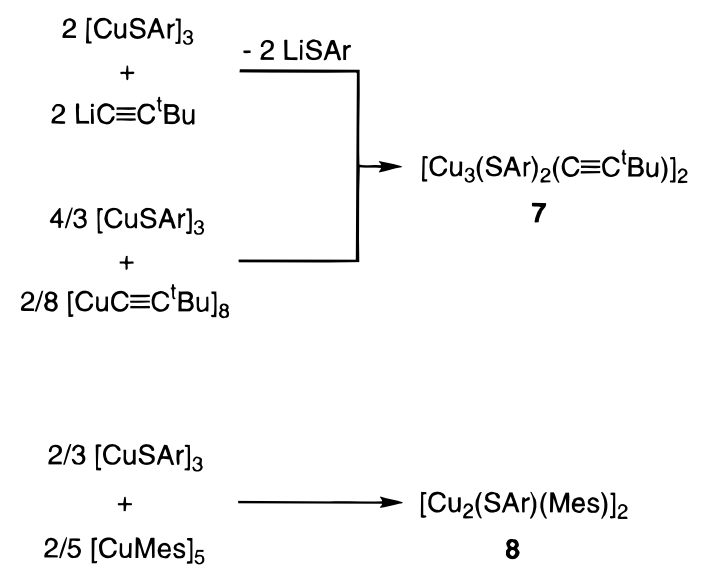

$$
\begin{aligned}
\mathrm{SAr} & =\mathrm{SC}_{6} \mathrm{H}_{4}\left(\mathrm{CH}(\mathrm{R}) \mathrm{NMe}_{2}\right)-2(\mathrm{R}=\mathrm{H}, \mathrm{Me}) \\
\mathrm{Mes} & =\mathrm{C}_{6} \mathrm{H}_{2} \mathrm{Me}_{3}-2,4,6
\end{aligned}
$$

ses were recorded on a Perkin-Elmer TGS-2 thermogravimetric system. Elemental analyses were carried out by Dornis und Kolbe Mikroanalytisches Laboratorium, Mülheim a.d. Ruhr, Germany. Cryoscopic molecular weight determinations of 5 were carried out in $\mathrm{C}_{6} \mathrm{H}_{6}$ at concentrations between 7 and $25 \mathrm{mg} / \mathrm{g}$ of $\mathrm{C}_{6} \mathrm{H}_{6}$ with naphthalene $(6$ $\mathrm{mg} / \mathrm{g}$ of $\left.\mathrm{C}_{6} \mathrm{H}_{6}\right)$ as internal reference. Commercial ${ }^{\mathrm{n}} \mathrm{BuLi}(1.67 \mathrm{M}$ in hexane) was used. [8-(Dimethylamino)-1-naphthyl]lithium-diethyl ether, ${ }^{13}\left[\mathrm{CuC} \equiv \mathrm{C}^{\mathrm{t} B u}\right],{ }^{14}$ and $\left[\mathrm{Cu}\left(\mathrm{C}_{6} \mathrm{H}_{2} \mathrm{Me}_{3}-2,4,6\right)\right]^{15}$ were prepared according to literature procedures.

Synthesis of $\mathrm{Me}_{3} \mathrm{SiSC}_{6} \mathrm{H}_{4} \mathrm{NMe}_{2}$-2. To 2-bromo- $N, N$-dimethylaniline $(42.79 \mathrm{~g}, 0.21 \mathrm{~mol})$ in hexane $(60 \mathrm{~mL})$ was added ${ }^{\mathrm{n}} \mathrm{BuLi}$ in hexane solution $(149 \mathrm{~mL}, 0.25 \mathrm{~mol})$ at $0{ }^{\circ} \mathrm{C}$. This mixture was stirred for 18 $\mathrm{h}$ at room temperature. The precipitate formed was collected by centrifugation of the reaction mixture and decantation of the supernatant. The white solid was washed with hexane $(3 \times 30 \mathrm{~mL})$ and dried in vacuo. Yield: $21.8 \mathrm{~g}(80 \%)$ of white solid $\mathrm{LiC}_{6} \mathrm{H}_{4} \mathrm{NMe}_{2}-2$.

$\mathrm{LiC}_{6} \mathrm{H}_{4} \mathrm{NMe}_{2}-2(21.8 \mathrm{~g}, 0.18 \mathrm{~mol})$ in THF $(150 \mathrm{~mL})$ was added to a vigorously stirred suspension of sublimed sulfur $(5.49 \mathrm{~g}, 0.17 \mathrm{~mol})$ in THF $(30 \mathrm{~mL})$ cooled below $-40{ }^{\circ} \mathrm{C}$. When the addition of $\mathrm{LiC}_{6} \mathrm{H}_{4}$ $\mathrm{NMe}_{2}-2$ was complete, the reaction mixture was slowly allowed to warm to $+10{ }^{\circ} \mathrm{C}$, and subsequently $\mathrm{Me}_{3} \mathrm{SiCl}(27 \mathrm{~mL}, 0.21 \mathrm{~mol})$ was added. During this procedure, the reaction mixture became a clear, slightly yellow solution. After $10 \mathrm{~min}$ of stirring, all solvent was removed in vacuo to afford a yellow oily residue. Distillation yielded $31.7 \mathrm{~g} \mathrm{(82 \% )}$ of $\mathrm{Me}_{3} \mathrm{SiSC}_{6} \mathrm{H}_{4} \mathrm{NMe}_{2}-2$ as a colorless oil; bp $67{ }^{\circ} \mathrm{C} / 0.45 \mathrm{mmHg} .{ }^{1} \mathrm{H}$ NMR (benzene- $\left.d_{6}, 297 \mathrm{~K}, 300.13 \mathrm{MHz}\right), \delta(\mathrm{ppm}): 0.17$ (s, $9 \mathrm{H}, \mathrm{Me}_{3} \mathrm{Si}$ ), $2.60\left(\mathrm{~s}, 6 \mathrm{H}, \mathrm{NMe}_{2}\right), 6.75\left(\mathrm{td}, 1 \mathrm{H},{ }^{3} J=7.4 \mathrm{~Hz},{ }^{4} J=1.4 \mathrm{~Hz}, \mathrm{ArH}-5\right)$, $6.81\left(\mathrm{dd}, 1 \mathrm{H},{ }^{3} J=6.7 \mathrm{~Hz},{ }^{4} J=1.4 \mathrm{~Hz}\right.$, ArH-3), $7.03\left(\mathrm{td}, 1 \mathrm{H},{ }^{3} J=\right.$ $\left.7.3 \mathrm{~Hz},{ }^{4} J=1.4 \mathrm{~Hz}, \mathrm{ArH}-4\right), 7.49\left(\mathrm{dd}, 1 \mathrm{H},{ }^{3} J=7.6 \mathrm{~Hz},{ }^{4} J=1.6 \mathrm{~Hz}\right.$, ArH-6). ${ }^{13} \mathrm{C}$ NMR (benzene- $\left.d_{6}, 297 \mathrm{~K}, 50.3 \mathrm{MHz}\right), \delta(\mathrm{ppm}): 1.36$ $\left(\mathrm{Me}_{3} \mathrm{Si}\right), 43.87\left(\mathrm{NMe}_{2}\right), 119.41$ (Ar-3), 122.74 (Ar-5), 126.93 (Ar-1), 128.14 (Ar-4), 137.80 (Ar-6), 156.04 (Ar-2). Anal. Calcd for $\mathrm{C}_{11} \mathrm{H}_{19^{-}}$ NSSi: C, 58.61; H, 8.50; N, 6.21. Found: C, 58.51; H, 8.47; N, 6.32.

Synthesis of $\mathrm{Me}_{3} \mathrm{SiS}-1-\mathrm{C}_{10} \mathrm{H}_{6} \mathrm{NMe}_{2}-8$. The preparation of $\mathrm{Me}_{3} \mathrm{SiS}-$ $1-\mathrm{C}_{10} \mathrm{H}_{6} \mathrm{NMe}_{2}-8$ is identical to that of $\mathrm{Me}_{3} \mathrm{SiSC}_{6} \mathrm{H}_{4} \mathrm{NMe}_{2}-2$ but starts

(13) (a) Jastrzebski, J. T. B. H; van Koten, G. Inorg. Synth. 1989, 26, 150155. (b) Jastrzebski, J. T. B. H.; van Koten, G.; Goubitz, K.; Arlen, C.; Pfeffer, M. J. Organomet. Chem. 1983, 246, C75-C79. (c) van der Zeijden, A. A. H.; van Koten, G. Recl. Trav. Chim. Pays-Bas 1988, 107, 431-433.

(14) (a) For a review on metal alkynyls see: (a) Nast, R. Coord. Chem. Rev. 1982, 47, 89-124. (b) [CuC $\equiv \mathrm{CPh}]_{\infty}$ : Corfield, P. W. R.; Shearer, H. M. M. In Organometallic Compounds, Vol. 2; Coates, G. E., Green, M. L. H., Wade, K., Eds.; Chapman and Hall: London, 1977. (c) $\left[\mathrm{CuC} \equiv \mathrm{C}^{\mathrm{B}} \mathrm{Bu}\right]_{8}$ : Coates, G. E.; Parkin, C. J. Inorg. Nucl. Chem. 1961, $22,59$.

(15) Meyer, E. M.; Gambarotta, S.; Floriani, C.; Chiesi-Villa, A.; Guastini, C. Organometallics 1989, 8, 1067-1079. from [8-(dimethylamino)-1-naphthyl]lithium-diethyl ether $(6.32 \mathrm{~g}$, $25.15 \mathrm{mmol})$ in THF $(150 \mathrm{~mL})$, sublimed sulfur $(0.81 \mathrm{~g}, 25.15 \mathrm{mmol})$ in THF $(50 \mathrm{~mL})$, and $\mathrm{Me}_{3} \mathrm{SiCl}(4.42 \mathrm{~mL}, 35 \mathrm{mmol})$. Yield: $5.4 \mathrm{~g}$ (78\%) of yellow $\mathrm{Me}_{3} \mathrm{SiS}-1-\mathrm{C}_{10} \mathrm{H}_{6} \mathrm{NMe}_{2}-8$. Bp: $103-110{ }^{\circ} \mathrm{C} / 0.5-0.8$ mmHg. Pure $\mathrm{Me}_{3} \mathrm{SiS}-1-\mathrm{C}_{10} \mathrm{H}_{6} \mathrm{NMe}_{2}-8$ has a melting point of $c a .20$ ${ }^{\circ} \mathrm{C}$. ${ }^{1} \mathrm{H}$ NMR (benzene- $d_{6}, 297 \mathrm{~K}, 200.13 \mathrm{MHz}$ ), $\delta$ (ppm): 0.02 (s, 9 $\left.\mathrm{H}, \mathrm{Me}_{3} \mathrm{Si}\right), 2.64\left(\mathrm{~s}, 6 \mathrm{H}, \mathrm{NMe}_{2}\right), 6.69\left(\mathrm{dd}, 1 \mathrm{H},{ }^{3} J=7.4 \mathrm{~Hz},{ }^{4} J=1.3\right.$ $\mathrm{Hz}, \mathrm{ArH}-7), 7.07$ (t, $\left.1 \mathrm{H},{ }^{3} J=7.9 \mathrm{~Hz}, \mathrm{ArH}-3\right), 7.21$ (t, $1 \mathrm{H},{ }^{3} J=7.9$ $\mathrm{Hz}$, ArH-6), $7.33\left(\mathrm{dd}, 1 \mathrm{H},{ }^{3} J=8.0 \mathrm{~Hz},{ }^{4} J=1.2 \mathrm{~Hz}\right.$, ArH-5), 7.52 $\left(\mathrm{dd}, 1 \mathrm{H},{ }^{3} J=8.1 \mathrm{~Hz},{ }^{4} J=1.2 \mathrm{~Hz}, \mathrm{ArH}-4\right), 7.73\left(\mathrm{dd}, 1 \mathrm{H},{ }^{3} J=7.2\right.$ $\mathrm{Hz},{ }^{4} J=1.3 \mathrm{~Hz}$, ArH-2). ${ }^{13} \mathrm{C}$ NMR (benzene- $\left.d_{6}, 75.5 \mathrm{MHz}\right), \delta$ (ppm): $1.17\left(\mathrm{Me}_{3} \mathrm{Si}\right), 44.85\left(\mathrm{NMe}_{2}\right), 115.30$ (Ar-7), 123.17 (Ar-5), 124.92 (Ar-6), 126.03 (Ar-3), 128.80 (Ar-4), 136.46 (Ar-2); other C signals not observed. The signal assignments of proton and carbon atoms at positions 5 and 6 are tentative. Anal. Calcd for $\mathrm{C}_{15} \mathrm{H}_{21^{-}}$ NSSi: C, 65.40; H, 7.68; N, 5.08. Found: C, 65.39; H, 7.66; N, 5.15.

Synthesis of $\left[\mathrm{Cu}\left(\mathrm{SC}_{6} \mathrm{H}_{4} \mathrm{NMe}_{2}-2\right)\right]_{3}(5)$. To a suspension of $\mathrm{CuCl}$ $(1.78 \mathrm{~g}, 17.9 \mathrm{mmol})$ in toluene $(20 \mathrm{~mL})$ was added at room temperature $\mathrm{Me}_{3} \mathrm{SiSC}_{6} \mathrm{H}_{4} \mathrm{NMe}_{2}-2(3.97 \mathrm{~g}, 17.6 \mathrm{mmol})$ in toluene $(30 \mathrm{~mL})$. The reaction mixture was stirred for $1 \mathrm{~h}$, after which the remaining $\mathrm{CuCl}$ was filtered off. All volatiles were then removed in vacuo. Yield: $3.8 \mathrm{~g}(100 \%)$ of crude $\mathbf{5}$. X-ray-suitable crystals could be obtained by slow distillation of pentane into a saturated solution of $\mathbf{5}$ in $\mathrm{CH}_{2} \mathrm{Cl}_{2}$. Mp: $186-188{ }^{\circ} \mathrm{C} . T_{\text {dec }}: 250{ }^{\circ} \mathrm{C}(\mathrm{TGA})$. Cryoscopy: $\mathrm{MW}=604 \pm$ 40 in the concentration range $0.4-42 \mathrm{~g} \cdot \mathrm{kg}^{-1}$ of benzene (calcd for $\left[\mathrm{Cu}\left(\mathrm{SC}_{6} \mathrm{H}_{4} \mathrm{NMe}_{2}-2\right)\right]_{3}:$ 647). MS (EI, m/e): $647\left[\mathrm{Cu}_{3}(\mathrm{SAr})_{3}\right]$ (calcd 647, 100\%), $495\left[\mathrm{Cu}_{3}(\mathrm{SAr})_{2}\right]^{+}$(calcd 495, 10\%), $430\left[\mathrm{Cu}_{2}(\mathrm{SAr})_{2}\right]$ (calcd 430, 10\%). ${ }^{1} \mathrm{H}$ NMR (benzene- $d_{6}, 200.13 \mathrm{MHz}$ ), $\delta$ (ppm): 2.42 (s, 6 $\left.\mathrm{H}, \mathrm{NMe}_{2}\right), 6.7-6.9(\mathrm{~m}, 3 \mathrm{H}, \mathrm{ArH}-3,4,5), 7.82\left(\mathrm{~d}, 1 \mathrm{H},{ }^{3} \mathrm{~J}=7.0 \mathrm{~Hz},{ }^{4} J\right.$ $=1.6 \mathrm{~Hz}$, ArH-6). ${ }^{13} \mathrm{C} \mathrm{NMR}$ (benzene- $\left.d_{6}, 75.5 \mathrm{MHz}\right), \delta(\mathrm{ppm}): 47.87$ $\left(\mathrm{NMe}_{2}\right), 121.30$ (Ar-3), 125.32 (Ar-5), 126.17 (Ar-4), 134.37 (Ar-6), 139.95 (Ar-1), 152.53 (Ar-2). Anal. Calcd for $\mathrm{C}_{24} \mathrm{H}_{30} \mathrm{Cu}_{3} \mathrm{~N}_{3} \mathrm{~S}_{3}$ : C, 44.53; H, 4.67; N, 6.49. Found: C, 44.54; H, 4.46; N, 6.49.

Synthesis of $\left[\mathrm{Cu}\left(\mathrm{S}-1-\mathrm{C}_{10} \mathrm{H}_{6} \mathrm{NMe}_{2}-8\right)\right]_{9}(6)$. The preparation of 6 is identical to that of $\mathbf{5}$ but starts from $\mathrm{CuCl}(0.69 \mathrm{~g}, 7.01 \mathrm{mmol})$ in benzene $(5 \mathrm{~mL})$ and $\mathrm{Me}_{3} \mathrm{SiS}-1-\mathrm{C}_{10} \mathrm{H}_{6} \mathrm{NMe}_{2}-2(1.93 \mathrm{~g}, 7.01 \mathrm{mmol})$ in benzene $(5 \mathrm{~mL})$. Yield: $1.7 \mathrm{~g}(90 \%)$ of crude red solid 6 . Pure 6 can be obtained by slow diffusion of pentane into a saturated solution in $\mathrm{CH}_{2} \mathrm{Cl}_{2}$. X-ray-suitable crystals were obtained by slowly cooling a concentrated benzene solution of 6 from reflux to $25^{\circ} \mathrm{C}$. Mp: $150-$ $156{ }^{\circ} \mathrm{C} . \quad T_{\text {dec }}: 225{ }^{\circ} \mathrm{C}$ (TGA). ${ }^{1} \mathrm{H}$ NMR (benzene- $d_{6}, 297 \mathrm{~K}, 200.13$ $\mathrm{MHz}$ ), $\delta$ (ppm): 2.87 (br s, $18 \mathrm{H}, \mathrm{NMe}_{2}$ ), 3.01 (br s, $18 \mathrm{H}, \mathrm{NMe}_{2}$ ), 3.32 (br s, $18 \mathrm{H}, \mathrm{NMe}_{2}$ ), 4.49 (t, $\left.3 \mathrm{H},{ }^{3} J=7.7 \mathrm{~Hz}, \mathrm{ArH}\right), 6.33(\mathrm{~m}, 6 \mathrm{H}, \mathrm{ArH}$ ), $6.48(\mathrm{~m}, 6 \mathrm{H}, \mathrm{ArH}), 6.60(\mathrm{~m}, 6 \mathrm{H}, \mathrm{ArH}), 7.1-7.4(\mathrm{~m}, 15 \mathrm{H}, \mathrm{ArH}), 7.5-$ $7.7(\mathrm{~m}, 12 \mathrm{H}, \mathrm{ArH}), 9.51(\mathrm{~m}, 6 \mathrm{H}, \mathrm{ArH})$. Minor species: $\delta 2.35\left(\mathrm{NMe}_{2}\right)$. For a discussion of the NMR data, vide infra. Anal. Calcd for $\mathrm{C}_{108} \mathrm{H}_{108} \mathrm{Cu}_{9} \mathrm{~N}_{9} \mathrm{~S}_{9}$ : C, 54.22; H, 4.55; N, 5.27. Found: $\mathrm{C}, 54.11 ; \mathrm{H}$, $4.58 ; \mathrm{N}, 5.17$.

Synthesis of $\left[\mathrm{Cu}_{3}\left(\mathrm{SC}_{10} \mathrm{H}_{6} \mathrm{NMe}_{2}-8\right)_{2}\left(\mathrm{C} \equiv \mathrm{C}^{t} \mathrm{Bu}\right)\right]_{2}(9)$. To 6 (1.19 g, $4.48 \mathrm{mmol})$ in benzene $(50 \mathrm{~mL})$ was added $\left[\mathrm{CuC} \equiv \mathrm{C}^{\mathrm{t}} \mathrm{Bu}\right](0.32 \mathrm{~g}, 2.24$ $\mathrm{mmol})$ in benzene $(10 \mathrm{~mL})$. The reaction mixture was stirred for $1 \mathrm{~h}$ and subsequently concentrated to a volume of about $15 \mathrm{~mL}$ in vacuo. Slow diffusion of hexane $(50 \mathrm{~mL})$ into this solution resulted in yellow 9. Yield: $1.49 \mathrm{~g}(99 \%)$. This material could not be redissolved in any noncoordinating solvent. X-ray-suitable crystals could be obtained by slow diffusion of hexane into a concentrated solution of 9 in pyridine. Experiments using different ratios of $\mathbf{6}$ to $\left[\mathrm{CuC} \equiv \mathrm{C}^{\mathrm{t}} \mathrm{Bu}\right]$ resulted in the quantitative formation of $\mathbf{9}$ and excess of either starting $\mathbf{6}$ or $[\mathrm{CuC} \equiv$ $\mathrm{C}^{\mathrm{t} B u}$ ]. Mp: $186{ }^{\circ} \mathrm{C}$ dec. $\mathrm{IR}(\mathrm{KBr}): \mathrm{C} \equiv \mathrm{C}$ not observed. ${ }^{1} \mathrm{H}$ NMR (pyridine- $\left.d_{5}, 200.13 \mathrm{MHz}\right), \delta(\mathrm{ppm}): 1.25\left(\mathrm{~s}, 9 \mathrm{H},{ }^{\mathrm{t}} \mathrm{Bu}\right), 2.72(\mathrm{~s}, 12 \mathrm{H}$, $\left.\mathrm{NMe}_{2}\right), 6.7-7.6(\mathrm{~m}, 10 \mathrm{H}, \mathrm{ArH}), 8.05\left(\mathrm{~d}, 2 \mathrm{H},{ }^{3} J=7 \mathrm{~Hz}, \mathrm{ArH}-2\right)$. Anal. Calcd for $\mathrm{C}_{60} \mathrm{H}_{66} \mathrm{Cu}_{6} \mathrm{~N}_{4} \mathrm{~S}_{4}$ : C, 53.28; H, 4.92; N, 4.14; $\mathrm{Cu}, 28.18$. Found: C, 53.12; H, 4.85; N, 4.19; Cu, 28.40.

Synthesis of $\left[\mathrm{Cu}_{2}\left(\mathrm{SC}_{10} \mathrm{H}_{6} \mathrm{NMe}_{2}-8\right)\left(\mathrm{C}_{6} \mathrm{H}_{2} \mathrm{Me}_{3}-2,4,6\right)\right]_{n}(10)$. To 6 $(1.06 \mathrm{~g}, 4.0 \mathrm{mmol})$ in toluene $(50 \mathrm{~mL})$ was added $[\mathrm{Cu}(\mathrm{Mes})](0.62 \mathrm{~g}$, $3.4 \mathrm{mmol})$ in toluene $(10 \mathrm{~mL})$. The reaction mixture was stirred for 1 $\mathrm{h}$ and subsequently concentrated to a volume of about $5 \mathrm{~mL}$ in vacuo. Slow cooling of this solution to $-20{ }^{\circ} \mathrm{C}$ resulted in yellow crystalline 10. Yield: $1.14 \mathrm{~g}(75 \%)$. Experiments using different ratios of 6 to $[\mathrm{Cu}(\mathrm{Mes})]$ resulted in lower yields of $\mathbf{1 0} .{ }^{1} \mathrm{H}$ NMR (benzene- $d_{6}, 297$ $\mathrm{K}, 300.13 \mathrm{MHz}), \delta(\mathrm{ppm}): 2.06(\mathrm{~s}, 3 \mathrm{H}, \mathrm{Me}), 2.13\left(\mathrm{~s}, 6 \mathrm{H}, \mathrm{NMe}_{2}\right), 2.23$ (s, 6H, Me), 6.5 (br s, 2H, ArH-2), 6.5-7.7 (br m, 7H, ArH). ${ }^{13} \mathrm{C}$ 
NMR (toluene- $\left.d_{8}, 75.5 \mathrm{MHz}\right), \delta$ (ppm): 21.5 (p-Me), $29.0(o-\mathrm{Me})$ $48.9\left(\mathrm{NMe}_{2}\right), 114.7,124.8,125.4,125.9,126.0,126.7,135.8,137.3$, 137.7, 138.9, 148.6, 152.0, 152.7 (Ar). Anal. Calcd for $\left[\mathrm{C}_{42} \mathrm{H}_{46^{-}}\right.$ $\left.\mathrm{Cu}_{4} \mathrm{~N}_{2} \mathrm{~S}_{2}\right]_{n}:$ C, 56.23; H, 5.17; N, 3.12; Cu, 28.33. Found: C, 56.17; $\mathrm{H}, 5.25 ; \mathrm{N}, 3.10 ; \mathrm{Cu}, 28.15$.

Mass Spectral Analysis of Mixtures of $[\mathrm{Cu}(\mathrm{SAr})]_{3}(5)$ and $[\mathrm{Cu}-$ $\left.\left(\mathbf{S A r}^{\prime}\right)\right]_{9}(\mathbf{6})$. Copper arenethiolates 5 and $\mathbf{6}$ were mixed and dissolved in $\mathrm{Et}_{2} \mathrm{O}$. From this solution was taken a sample of $1 \mu \mathrm{L}$, and after evaporation of the solvent, the solid sample was brought directly into the mass spectrometer.

Structure Determination and Refinement of 5, 6, and 9. Crystals of 5, 6, and 9 were obtained as described above. X-ray data were collected on an Enraf-Nonius CAD4T/rotating-anode diffractometer for a transparent yellow column-shaped $(0.35 \times 0.50 \times 1.50 \mathrm{~mm})$ crystal (5), a transparent red hexagonal-prismatic crystal $(0.05 \times 0.20 \times 0.20$ $\mathrm{mm})(\mathbf{6})$, or a transparent yellow column-shaped crystal $(0.08 \times 0.20$ $\times 0.75 \mathrm{~mm})(9)$ glued on top of a glass fiber using graphitemonochromated Mo $\mathrm{K} \alpha$ radiation $(\lambda=0.71073 \AA)$. Accurate unitcell parameters and an orientation matrix were derived from the setting angles of 25 well-centered reflections (SET4) ${ }^{16}$ in the range $10^{\circ}<\theta$ $<14^{\circ}$. The unit-cell parameters were checked for the presence of higher lattice symmetry. ${ }^{17}$ Data were corrected for Lorentz-polarization effects and for absorption (DIFABS, ${ }^{18} \mathbf{5}$ and $\mathbf{9}$ only; transmission ranges $0.48-1.0(\mathbf{5})$ and $0.76-1.0(\mathbf{9}))$.

Structure of $\mathbf{5}$. The structure of $\mathbf{5}$ was solved by direct methods (SHELXS86) ${ }^{19}$ and difference Fourier techniques and refined on $F$ by full-matrix least squares (SHELX76) ${ }^{20}$ to an $R=0.028$ for 1009 reflections with $I>2.5 \sigma(I)$ and 107 variables. The opposite enantiomer refined to a higher $R$ value. Hydrogen atoms were introduced on calculated positions and refined riding on their carrier atoms. All nonhydrogen atoms were refined with anisotropic thermal parameters. A final Fourier map showed no residual density outside -0.84 and 0.41 $\mathrm{e} / \AA^{3}$ (near the phenyl ring). Neutral-atom scattering factors were taken from Cromer and Mann, ${ }^{21}$ anomalous dispersion corrections, from Cromer and Liberman. ${ }^{22}$

Structure of 6 . The $\mathrm{Cu}_{9} \mathrm{~S}_{9}$ core of the structure of $\mathbf{6}$ was solved by direct methods (SIR92), ${ }^{23}$ and difference Fourier techniques and subsequent refinement cycles (SHELXL93) ${ }^{24}$ were used to solve the complete structure. Refinement on $F^{2}$ by full-matrix least squares (SHELXL93) $^{24}$ converged to an $R_{1}=0.118$ [9344 reflections $I>$ $2.5 \sigma(I)]$ for 1501 variables. Hydrogen atoms were introduced on calculated positions and refined riding on their carrier atoms. All Cu and $\mathrm{S}$ atoms were refined with anisotropic thermal parameters, while all $\mathrm{C}, \mathrm{H}$, and $\mathrm{N}$ atoms were refined with isotropic thermal parameters. A final Fourier map showed no residual density outside -1.08 and $1.16 \mathrm{e} / \AA^{3}$ (near the $\mathrm{Cu}_{9} \mathrm{~S}_{9}$ core). Neutral-atom scattering factors and anomalous dispersion corrections were taken from ref 25 .

Structure of 9. The structure of $\mathbf{9}$ was solved by direct methods (DIRDIF92) $^{26}$ and refined on $F$ by full-matrix least squares (SHELX76) ${ }^{20}$ to $R=0.0314$ for 5110 reflections with $I \geq 2.5 \sigma(I)$ and 358 variables. Hydrogen atoms were introduced on calculated positions and refined riding on their carrier atoms. All non-hydrogen atoms were refined with anisotropic atomic displacement parameters. Hydrogen atoms were refined with common isotropic atomic displacement parameters

(16) de Boer, J. L.; Duisenberg, A. J. M. Acta Crystallogr. 1984, A40, C410.

(17) Spek, A. L. J. Appl. Crystallogr. 1988, 21, 578.

(18) Walker, N.; Stuart, D. Acta Crystallogr. 1983, A39, 158-166.

(19) Sheldrick, G. M. SHELXS86. Program for crystal structure determination; University of Göttingen: Göttingen, Germany, 1986.

(20) Sheldrick, G. M. SHELX76. Program for crystal structure analysis; University of Cambridge: Cambridge, U.K., 1976.

(21) Cromer, D. T.; Mann, J. B. Acta Crystallogr. 1968, A24, 321-325.

(22) Cromer, D. T.; Liberman, D. J. Chem. Phys. 1970, 53, 1891-1898.

(23) Altomare, A.; Cascarano, G.; Giacovazzo, C.; Guagliardi, A. J. Appl. Crystallogr. 1993, 26, 343-350.

(24) Sheldrick, G. M. SHELXL93. Program for crystal structure refinement; University of Göttingen: Göttingen, Germany, 1993.

(25) Wilson, A. J. C., Ed.; International Tables for Crystallography; Kluwer Academic Publishers: Dordrecht, The Netherlands, 1992; Vol. C.

(26) Beurskens, P. T.; Admiraal, G.; Beurskens, G.; Bosman, W. P.; GarcíaGranda, S.; Gould, R. O.; Smits, J. M. M.; Smykalla, C. The DIRDIF Program System; Technical Report; Crystallography Laboratory, University of Nijmegen: Nijmegen, The Netherlands, 1992.
Table 1. Experimental Data for the X-ray Diffraction Studies of 5, $\mathbf{6}$, and $\mathbf{9}$

\begin{tabular}{|c|c|c|c|}
\hline & 5 & 6 & 9 \\
\hline formula & $\mathrm{C}_{24} \mathrm{H}_{30} \mathrm{Cu}_{3} \mathrm{~N}_{3} \mathrm{~S}_{3}$ & $\mathrm{C}_{279} \mathrm{H}_{279} \mathrm{Cu}_{18} \mathrm{~N}_{18} \mathrm{~S}_{18}$ & $\mathrm{C}_{60} \mathrm{H}_{66} \mathrm{Cu}_{6} \mathrm{~N}_{4} \mathrm{~S}_{4}$ \\
\hline & 647.36 & 5605.4 & 1352.75 \\
\hline space group & $R 3$ & $P \overline{1}$ & $P 2_{1} / c$ \\
\hline crystal system & trigonal & triclinic & monoclinic \\
\hline$Z$ & 3 & 2 & 2 \\
\hline$a(\AA)$ & $18.2325(7)$ & $16.081(2)$ & $11.9839(5)$ \\
\hline$b(\AA)$ & $18.2325(7)$ & $26.650(4)$ & 12.9391(8) \\
\hline$c(\AA)$ & $6.8410(4)$ & $32.747(6)$ & $18.9482(7)$ \\
\hline$\alpha(\operatorname{deg})$ & 90 & $67.320(13)$ & \\
\hline$\beta$ (deg) & 90 & $76.180(12)$ & $108.326(3)$ \\
\hline$\gamma(\mathrm{deg})$ & 120 & $81.226(12)$ & \\
\hline$V\left(\AA^{3}\right)$ & $1969.4(2)$ & $12545(4)$ & $2789.1(2)$ \\
\hline$d_{\text {calc }}\left(\mathrm{g} \cdot \mathrm{cm}^{-3}\right)$ & 1.637 & 1.484 & 1.611 \\
\hline$\mu(\operatorname{Mo~K\alpha })\left(\mathrm{cm}^{-1}\right)$ & 26.6 & 17.0 & 24.4 \\
\hline$\lambda(\mathrm{Mo} \mathrm{K} \alpha)(\AA)$ & 0.71073 & 0.71073 & 0.71073 \\
\hline$T(\mathrm{~K})$ & 100 & 150 & 150 \\
\hline$R^{a}$ & $0.028^{b}$ & $0.118^{c}$ & $0.0314^{b}$ \\
\hline $\mathrm{w} R / \mathrm{w} R_{2}$ & $0.036^{b}$ & $0.306^{c}$ & $0.0417^{b}$ \\
\hline
\end{tabular}

Scheme 2. Synthesis of Copper(I) Arenethiolates 5 and 6<smiles>C[SiH3]Sc1ccccc1N(C)CCCC(C)(C)Cl</smiles>

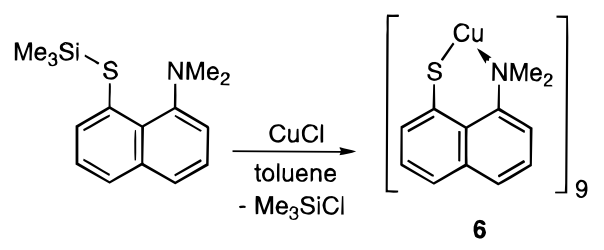

for the $\mathrm{C} \equiv \mathrm{C}^{t} \mathrm{Bu}, \mathrm{C}_{10} \mathrm{H}_{6}$, and $\mathrm{NMe}_{2}$ groups. Weights were optimized in the final refinement cycles. A final Fourier map showed no residual density outside -0.63 and $0.39 \mathrm{e}^{\circ} \AA^{3}$ (near Cu1). Neutral-atom scattering factors were taken from Cromer and Mann; ${ }^{21}$ anomalous dispersion corrections, from Cromer and Liberman. ${ }^{22}$

Geometrical calculations and illustrations were performed with PLATON. ${ }^{27}$ All calculations were performed on a DEC5000 cluster. Crystal data and numerical details of the structure determinations are given in Table 1. Selected geometrical details of 5, 6, and $\mathbf{9}$ are listed in Tables $2-4$, respectively.

\section{Results}

The new complexes [2-(dimethylamino)benzenethiolato]copper(I) (5) and [8-(dimethylamino)naphthalene-1-thiolato]copper(I) (6) were obtained from the reaction of equimolar amounts of the corresponding reagents $\mathrm{Me}_{3} \mathrm{SiSAr}\left(\mathrm{Ar}=\mathrm{C}_{6} \mathrm{H}_{4}\right.$ $\mathrm{NMe}_{2}-2$ or $1-\mathrm{C}_{10} \mathrm{H}_{6} \mathrm{NMe}_{2}-8$ ) and copper(I) chloride in toluene (Scheme 2). The reaction starts immediately on mixing of the reagents, and one sees a color change of the mixture from colorless to yellow (5) or red (6) and dissolution of the $\mathrm{CuCl}$; the reaction which can be accelerated by gentle heating $( \pm 40$ ${ }^{\circ} \mathrm{C}$ ) was followed by ${ }^{1} \mathrm{H}$ NMR spectroscopy.

The reaction is clean, and pure $\mathbf{5}$ and $\mathbf{6}$ are obtained as solid materials by simple evaporation of the volatiles (solvent and $\mathrm{Me}_{3} \mathrm{SiCl}$ ). Any excess $\mathrm{CuCl}$ can be removed by filtration of the reaction mixture prior to concentration, while an excess of

(27) Spek, A. L. Acta Crystallogr. 1990, A46, C34. 


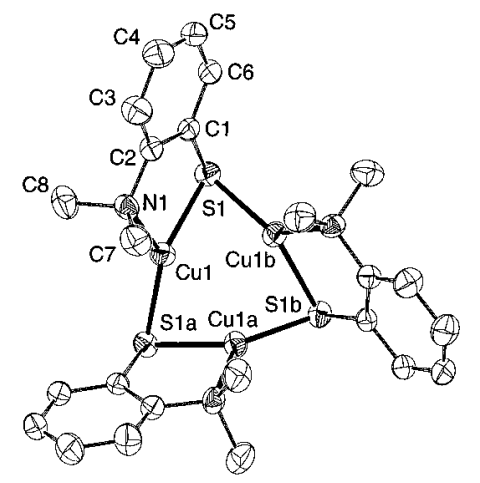

Figure 1. ORTEP drawing (50\% probability level) of $\left[\mathrm{Cu}\left(\mathrm{SC}_{6} \mathrm{H}_{4} \mathrm{NMe}_{2}-\right.\right.$ $2)]_{3}(\mathbf{5})$ (excluding the hydrogen atoms) with the atom-labeling scheme.

Table 2. Selected Geometrical Data for $\left[\mathrm{Cu}\left(\mathrm{SC}_{6} \mathrm{H}_{4} \mathrm{NMe}_{2}-2\right)\right]_{3}(\mathbf{5})^{a}$

\begin{tabular}{llll}
\hline \multicolumn{5}{c}{ Bond Lengths $(\AA)$} \\
$\mathrm{Cu} 1-\mathrm{S} 1$ & $2.198(1)$ & $\mathrm{Cu} 1 \cdots \mathrm{Cu} 1 \mathrm{a}$ & $2.6962(8)$ \\
$\mathrm{Cu} 1-\mathrm{S} 1 \mathrm{~b}$ & $2.2219(9)$ & $\mathrm{Cu} 1 \cdots \mathrm{Cu} 1 \mathrm{~b}$ & $2.6962(8)$ \\
$\mathrm{Cu} 1-\mathrm{N} 1 \mathrm{~b}$ & $2.170(4)$ & $\mathrm{S} 1-\mathrm{C} 1$ & $1.775(4)$ \\
\multicolumn{5}{c}{} \\
$\mathrm{Cu} 1-\mathrm{S} 1-\mathrm{Cu} 1 \mathrm{a}$ & \multicolumn{2}{c}{ Bond Angles $(\mathrm{deg})$} \\
$\mathrm{S} 1-\mathrm{Cu} 1-\mathrm{N} 1 \mathrm{~b}$ & $128.59(9)$ & $\mathrm{Cu} 1-\mathrm{S} 1-\mathrm{C} 1$ & $108.3(1)$ \\
$\mathrm{S} 1-\mathrm{Cu} 1-\mathrm{S} 1 \mathrm{~b}$ & $141.58(4)$ & $\mathrm{Cu} 1 \mathrm{a}-\mathrm{S} 1-\mathrm{C} 1$ & $97.5(1)$ \\
\end{tabular}

${ }^{a}$ The estimated standard deviations of the last significant digits are shown in parentheses. Symmetry operations: (a) $=-y, x-y, z$; (b) $=-x+y,-x, z$.

$\mathrm{Me}_{3} \mathrm{SiSAr}$ can be removed by washing of the residue with pentane, in which $\mathbf{5}$ and $\mathbf{6}$ are poorly soluble.

Copper arenethiolate $\mathbf{5}$ is a white (sometimes slightly yellow) solid which has a melting point of $186-188^{\circ} \mathrm{C}$. Thermogravimetric analysis (TGA) of $\mathbf{5}$ shows that decomposition occurs above $250{ }^{\circ} \mathrm{C}$. Surprisingly, although copper arenethiolates are generally pale yellow, the (1-naphthalenethiolato)copper complex 6 is a red solid which melts at $150-156{ }^{\circ} \mathrm{C}$ and which decomposes above $225^{\circ} \mathrm{C}$ (TGA). Both copper arenethiolates 5 and $\mathbf{6}$ are very soluble in aromatic and chlorinated hydrocarbons (e.g. benzene, toluene, chloroform, and dichloromethane), less soluble in diethyl ether and THF, and poorly soluble in alkanes. Solid 5 and $\mathbf{6}$ do not show any visible change upon exposure to air for short periods. However, when exposed to air, solutions of $\mathbf{5}$ quickly turn green and solutions of $\mathbf{6}$ become yellow within $30 \mathrm{~min}$.

Structure of Trimeric 5 in the Solid State. The molecular structure of $\left[\mathrm{Cu}\left(\mathrm{SC}_{6} \mathrm{H}_{4} \mathrm{NMe}_{2}-2\right)\right]_{3}(5)$ in the solid state shows the complex to be trimeric (Figure 1). Selected geometrical details of $\mathbf{5}$ are listed in Table 2.

Complex 5 crystallizes in the asymmetric space group $R 3$, which is surprising since no chiral functionalities were used during synthesis. However, screw-type chirality is induced in the structure by the nonplanarity of the trimeric aggregate in combination with the formation of three identical $\mathrm{Cu}-\mathrm{S}-\mathrm{C}-$ $\mathrm{C}-\mathrm{N}$ five-membered chelates. The crystal of $\mathbf{5}$ chosen for the $\mathrm{X}$-ray diffraction study contains only one enantiomer (as depicted in Figure 1). Of course, crystalline bulk material 5 contains both enantiomers in a 1:1 ratio.

The trimeric structure of $\mathbf{5}$ is based on a cyclohexane-like six-membered $\mathrm{Cu}_{3} \mathrm{~S}_{3}$ ring in a chair conformation with alternating copper and sulfur atoms. The sulfur atom of each of the arenethiolate ligands bridges two copper atoms, and all aryl groups are in an equatorial position relative to the $\mathrm{Cu}_{3} \mathrm{~S}_{3}$ ring. This structure is very similar to that reported earlier for $\left[\mathrm{Cu}\left(\mathrm{SC}_{6} \mathrm{H}_{4} \mathrm{CH}(\mathrm{Me}) \mathrm{NMe}_{2}-2\right)\right]_{3} \cdot{ }^{2 \mathrm{a}}$

The copper atoms in $\mathbf{5}$ have a distorted trigonal-planar geometry resulting from the bonding to two sulfur atoms and
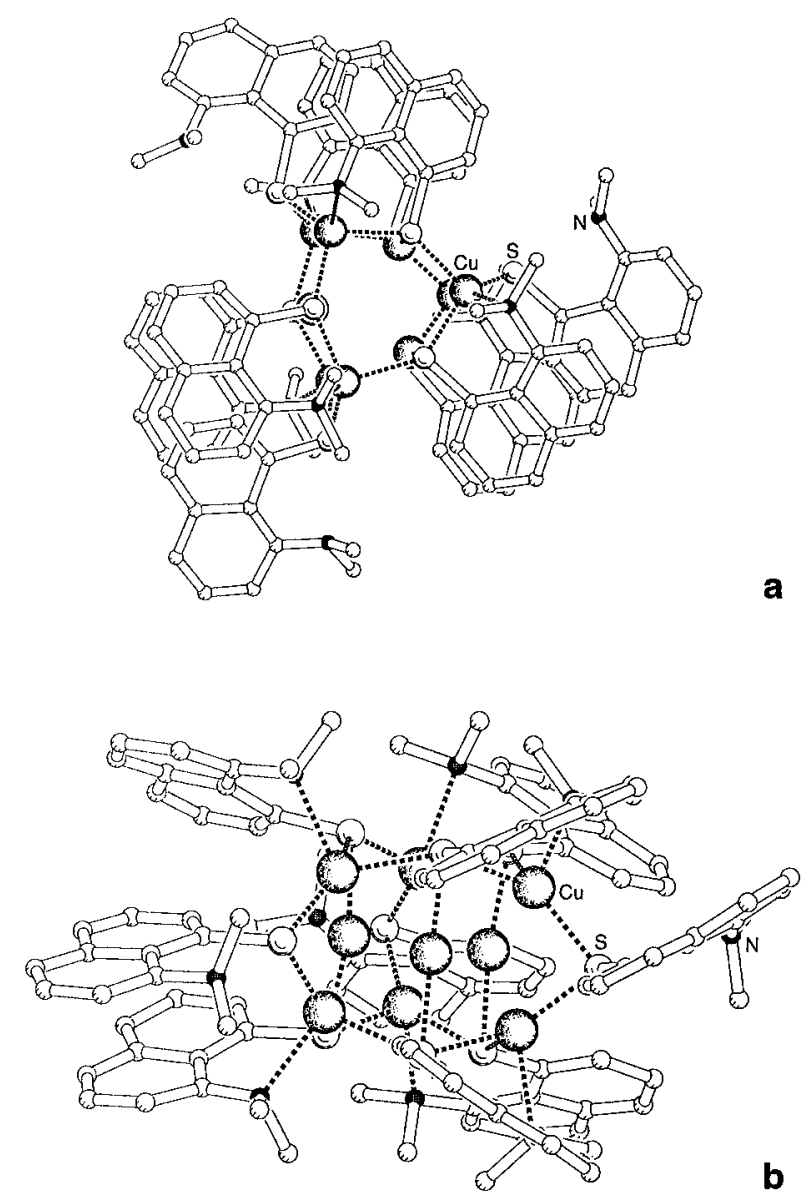

Figure 2. PLUTON drawing of one of the two independent residues of nonameric $\left[\mathrm{Cu}\left\{\mathrm{S}-1-\mathrm{C}_{10} \mathrm{H}_{6} \mathrm{NMe}_{2}-8\right\}\right]_{9}$ (6): (a) top view; (b) side view.

one nitrogen atom $\left(\sum^{\circ} \mathrm{Cu}=359.8^{\circ}\right)$. The copper-sulfur distances, $\mathrm{Cu} 1-\mathrm{S} 1$ of 2.2219(9) $\AA$ (within chelate) and $\mathrm{Cu} 1-$ S1b of 2.198(1) $\AA$ (to neighboring chelate), are in the expected range for copper(I) arenethiolates. The $\mathrm{Cu} 1-\mathrm{N} 1 \mathrm{~b}$ distance of $2.170(4) \AA$ is slightly longer than comparable bonds found in the hexanuclear aggregates $\left[\mathrm{Cu}_{6} \mathrm{Br}_{2}\left(\mathrm{C}_{6} \mathrm{H}_{4} \mathrm{NMe}_{2}-2\right)_{4}\right]^{28}$ and $\left[\mathrm{Cu}_{6}\left(\mathrm{C}_{6} \mathrm{H}_{4} \mathrm{NMe}_{2}-2\right)_{4}\left(\mathrm{C} \equiv \mathrm{CC}_{6} \mathrm{H}_{4} \mathrm{Me}-4\right)_{2}\right],{ }^{29}$ where the $\mathrm{Cu}-\mathrm{N}$ distances average 2.11 and $2.114(8) \AA$, respectively. The $\mathrm{Cu} 1-$ $\mathrm{S} 1-\mathrm{Cu} 1 \mathrm{a}$ angle of $75.18(4)^{\circ}$ is acute, and is representative for a two-electron three-center $(2 \mathrm{e}-3 \mathrm{c})$ bonding of the arenethiolate. ${ }^{2 \mathrm{a}}$

Structure of Nonameric 6 in the Solid State. The molecular structure of $\mathbf{6}$, determined by an X-ray analysis, shows that this complex is a nonameric species (Figure 2). In the crystal structure, the asymmetric unit of $\mathbf{6}$ contains two crystallographically independent nonameric aggregates $\left[\mathrm{Cu}\left(\mathrm{S}-1-\mathrm{C}_{10} \mathrm{H}_{6} \mathrm{NMe}_{2}-\right.\right.$ $8)]_{9}$ as well as 10.5 independent molecules of benzene from which 6 was crystallized. The two aggregates are enantiomers whose structural parameters correspond very closely (bond distances and bond angles in each residue average to the same values within $0.01 \AA$ and within $1^{\circ}$, respectively). Thus, to avoid excessive tabulation, the bond distances and averages have been listed by range and average (Table 3). A complete listing of bond lengths and bond angles, including ranges and averages for each independent residue is available as Supporting Information.

Each nonameric aggregate of $\mathbf{6}$ can be seen as a layered structure with two trinuclear $\left[\mathrm{Cu}_{3}(\mathrm{SAr})_{3}\right]$ units, similar to the

(28) Guss, J. M.; Mason, R.; Thomas, K. M.; van Koten, G.; Noltes, J. G. J. Organomet. Chem. 1972, 40, C79-C 80.

(29) ten Hoedt, R. W. M.; Noltes, J. G.; van Koten, G.; Spek, A. L. J. Chem. Soc., Dalton Trans. 1978, 1800-1806. 
Table 3. Bond Lengths $(\AA)$ and Bond Angles (deg) for $\left[\mathrm{Cu}\left(\mathrm{S}-1-\mathrm{C}_{10} \mathrm{H}_{6} \mathrm{NMe}_{2}-8\right)\right]_{9}(\mathbf{6})^{a}$
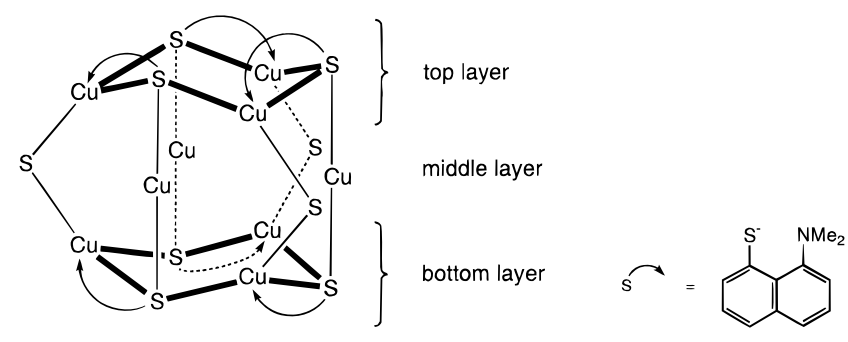

\begin{tabular}{lcl}
\hline & range & average \\
\hline & Within either Top or Bottom Layer \\
$\mathrm{Cu}-\mathrm{S}^{b}$ & $2.293(9)-2.346(7)$ & 2.32 \\
$\mathrm{Cu}-\mathrm{S}^{c}$ & $2.350(7)-2.429(8)$ & 2.38 \\
$\mathrm{Cu} \cdots \mathrm{Cu}$ & $4.178(5)-4.289(5)$ & 4.23 \\
$\mathrm{Cu}-\mathrm{N}$ & $2.28(2)-2.54(2)$ & 2.37 \\
$\mathrm{Cu}-\mathrm{S}-\mathrm{Cu}$ & $127.1(3)-130.7(4)$ & 129 \\
$\mathrm{~S}-\mathrm{Cu}-\mathrm{S}$ & $92.5(3)-97.4(3)$ & 95
\end{tabular}

Interaction from Middle to Top/Bottom Layer

\begin{tabular}{lll}
$\mathrm{S}^{\mathrm{m}}-\mathrm{Cu}$ & $2.238(7)-2.273(8)$ & 2.26 \\
$\mathrm{Cu}^{\mathrm{m}}-\mathrm{S}$ & $2.192(8)-2.207(9)$ & 2.20 \\
$\mathrm{Cu}^{\mathrm{m}} \cdots \mathrm{Cu}$ & $2.593(5)-2.737(5)$ & 2.66 \\
$\mathrm{Cu}^{\mathrm{m}}-\mathrm{S}-\mathrm{Cu}$ & $69.6(2)-74.2(3)$ & 71 \\
$\mathrm{~S}^{\mathrm{m}}-\mathrm{Cu}-\mathrm{S}^{b}$ & $136.0(3)-142.4(3)$ & 140 \\
$\mathrm{~S}^{\mathrm{m}}-\mathrm{Cu}-\mathrm{S}^{c}$ & $117.7(3)-122.3(3)$ & 119 \\
\multicolumn{4}{r}{} \\
$\mathrm{Cu} \cdot \mathrm{Cu}$ & Interaction from Top to Bottom Layer \\
$\mathrm{S}-\mathrm{Cu}-\mathrm{S}$ & $2.998(5)-3.097(5)$ & 3.04 \\
$\mathrm{Cu}-\mathrm{S}-\mathrm{Cu}$ & $166.1(3)-167.8(3)$ & 167 \\
& $83.2(3)-87.2(2)$ & 85
\end{tabular}

${ }^{a}$ The estimated standard deviations of the last significant digits are shown in parentheses. Atoms in the middle-layer are labeled $\mathrm{m}$. ${ }^{b}$ Within chelate. ${ }^{c}$ To neighboring chelate.

overall structure of $\mathbf{5}$, forming the top and bottom layers (atoms labeled with superscripts $t$ and $b$, respectively). These two units are held together by a middle layer (atoms labeled with superscript $\mathrm{m}$ ) comprising three two-coordinate copper atoms that bridge from one $\mathrm{S}$ in $\mathrm{Cu}_{3} \mathrm{~S}_{3}$ to the opposite $\mathrm{S}$ in $\mathrm{Cu}_{3}{ }_{3} \mathrm{~S}_{3}{ }_{3}$, as well as three $\mu_{2}-\mathrm{S}$-bridging arenethiolate ligands that bridge from one $\mathrm{Cu}$ in $\mathrm{Cu}_{3} \mathrm{~S}_{3}{ }_{3}$ to the opposite $\mathrm{Cu}$ in $\mathrm{Cu}_{3} \mathrm{~S}_{3} \mathrm{~b}_{3}$. The nitrogen donor atoms from the arenethiolates in the top and the bottom layer coordinate to adjacent copper atoms within the same layer, but the nitrogen donor atoms from the arenethiolate ligands in the middle layer are not coordinating at all. In this way, a $\left[\mathrm{Cu}_{9} \mathrm{~S}_{9}\right]$ core is formed which comprises eight fused sixmembered $\mathrm{Cu}_{3} \mathrm{~S}_{3}$ rings: two for the top and bottom layers and six for the side faces of the aggregate.

Each copper atom in the top and bottom layers is fourcoordinate with bonds from two sulfur atoms of the arenethiolate ligands $(\mathrm{Cu}-\mathrm{S}$ (within chelate) is $2.32 \AA, \mathrm{Cu}-\mathrm{S}$ (to neighboring chelate) is $2.38 \AA$ ), one coordination bond from a nitrogen atom within the same layer $(\mathrm{Cu}-\mathrm{N}$ is $2.37 \AA$ ) and one bond from a sulfur atom of an arenethiolate ligand of the middle layer $(\mathrm{Cu}-\mathrm{S}$ is $2.26 \AA$ ). The arenethiolates in the top and bottom layers are $\mu_{3}-\mathrm{S}$-bridging over two copper atoms from that layer (vide supra) and one copper from the middle layer $(\mathrm{Cu}-\mathrm{S} 2.20 \AA)$.

The coordination geometry of the sulfur atoms of the arenethiolate ligands in the top and bottom layers is significantly distorted from tetrahedral, as the mean value of $\mathrm{Cu}^{\mathrm{t}}-\mathrm{S}^{\mathrm{t}}-\mathrm{Cu}^{\mathrm{t}}$ and $\mathrm{Cu}^{\mathrm{b}}-\mathrm{S}^{\mathrm{b}}-\mathrm{Cu}^{\mathrm{b}}$ is $129^{\circ}$ and the angles $\mathrm{Cu}^{\mathrm{t}}-\mathrm{S}^{\mathrm{t}}-\mathrm{Cu}^{\mathrm{m}}$ and $\mathrm{Cu}^{\mathrm{b}}-$ $\mathrm{S}^{\mathrm{b}}-\mathrm{Cu}^{\mathrm{m}}$ average to $71^{\circ}$. This distortion is further visible from the angles $\mathrm{Cu}^{\mathrm{m}}-\mathrm{S}^{\mathrm{t}}-\mathrm{C}$ and $\mathrm{Cu}^{\mathrm{m}}-\mathrm{S}^{\mathrm{b}}-\mathrm{C}$ of $102^{\circ}$ (mean; range 100.5(8)-106.7(10) ${ }^{\circ}$, the angles $\mathrm{Cu}^{\mathrm{t}}-\mathrm{S}^{\mathrm{t}}-\mathrm{C}$ and $\mathrm{Cu}^{\mathrm{b}}-\mathrm{S}^{\mathrm{b}}-\mathrm{C}$ within the $\mathrm{Cu}-\mathrm{S}-\mathrm{C}-\mathrm{C}-\mathrm{C}-\mathrm{N}$ chelate of $104^{\circ}$ (mean; range 99.3(7)-106.1(9) ${ }^{\circ}$, and especially the angles $\mathrm{Cu}^{\mathrm{t}}-\mathrm{S}^{\mathrm{t}}-\mathrm{C}$ and
$\mathrm{Cu}^{\mathrm{b}}-\mathrm{S}^{\mathrm{b}}-\mathrm{C}$ to the neighboring chelate of $118^{\circ}$ (mean; range 115.1(9)-121.7(8) ${ }^{\circ}$.

The three arenethiolate ligands in the middle layer display acute $\mathrm{Cu}^{\mathrm{t}}-\mathrm{S}^{\mathrm{m}}-\mathrm{Cu}^{\mathrm{b}}$ angles of $85^{\circ}$ (mean), and the angles $\mathrm{Cu}^{\mathrm{t}}-$ $\mathrm{S}^{\mathrm{m}}-\mathrm{C}$ and $\mathrm{Cu}^{\mathrm{b}}-\mathrm{S}^{\mathrm{m}}-\mathrm{C}$ of $109^{\circ}$ (mean; range 101.6(9)$\left.112.9(10)^{\circ}\right)$ are consistent with a tetrahedral geometry for these sulfur atoms. As in the structure of $\mathbf{5}$, the acute $\mathrm{Cu}^{\mathrm{t}}-\mathrm{S}^{\mathrm{m}}-\mathrm{Cu}^{\mathrm{b}}$ angles suggest a two-electron three-center $(2 \mathrm{e}-3 \mathrm{c})$ bonding of arenethiolate ligands in the middle layer.

An alternative description of the geometry of the nonameric structure of 6 is as an aggregate comprising three $\left[\mathrm{Cu}(\mathrm{SAr})_{2}\right]^{-}$ cuprate moieties that are held together by three $\left[\mathrm{Cu}_{2}(\mathrm{SAr})\right]^{+}$ entities. The short $\mathrm{Cu}^{\mathrm{m}}-\mathrm{S}$ contacts in the structure of $6\left(\mathrm{Cu}^{\mathrm{m}}\right.$ $\mathrm{S}^{\mathrm{t}}$ and $\mathrm{Cu}^{\mathrm{m}}-\mathrm{S}^{\mathrm{b}}$ bond lengths of $2.20 \AA$ ) as well as the almost linear geometry of the copper atoms in the middle layer $\left(\mathrm{S}^{\mathrm{t}}-\right.$ $\mathrm{Cu}^{\mathrm{m}}-\mathrm{S}^{\mathrm{b}}=167^{\circ}$ ) are in agreement with this description. However, the present results do not allow us to examine the validity of this description in detail and one has to await the results of computational studies for further insights into the bonding in this structure.

Stereochemical Consequences of the Structure of 6 . It should be noted that the coordination of nitrogen to copper in the presence of a nonplanar six-membered $\left[\mathrm{Cu}_{3}(\mathrm{SAr})_{3}\right]$ entity induces screw-type chirality. For the nonameric aggregate 6 this means that there are in principle four diastereoisomers possible, namely two enantiomers and two mesomers which result from combinations of clockwise and anticlockwise screwtype chirality in the top and bottom $\mathrm{Cu}_{3}(\mathrm{SAr})_{3}$ layers. During the course of the X-ray structure studies, the measurement of four different crystals of $\mathbf{6}$ showed that these diastereoisomeric combinations are indeed possible.

Structures of 5 and 6 in Solution. Cryoscopic measurements of $\mathbf{5}$ in benzene show it to be also trimeric in solution. However, if $\mathrm{Cu}-\mathrm{N}$ coordination is present as in the solid state structure, one has a trimeric structure which is not flat and each $\mathrm{NMe}_{2}$ group should afford two different Me group NMR resonances. However, only one $\mathrm{NMe}_{2}$ signal is observed in both ${ }^{1} \mathrm{H}$ and ${ }^{13} \mathrm{C}$ NMR spectra even at low temperatures (193 $\mathrm{K})$. A plausible explanation for this is that nitrogen-to-copper coordination is weak and that $\mathrm{Cu}-\mathrm{N}$ dissociation/association is fast on the NMR time scale. This reasoning would indicate that $\mathrm{N} \rightarrow \mathrm{Cu}$ coordination in $\mathbf{5}$ is weaker than that in closely related $\left[\mathrm{Cu}\left(\mathrm{SC}_{6} \mathrm{H}_{4} \mathrm{CH}_{2} \mathrm{NMe}_{2}-2\right)\right]_{3}$ (1a) where the $\Delta G^{\ddagger}$ for this process is reported to be $48 \mathrm{~kJ} / \mathrm{mol}$; $2 \mathrm{a}$ this is reasonable since the Lewis basicity of the $\mathrm{NMe}_{2}$ group in $\mathbf{5}$ (aromatic amine) is lower than that in 1a (benzylic amine). On geometrical grounds, one would expect in $\mathbf{5}$ a stronger $\mathrm{Cu}-\mathrm{N}$ bonding than in $\mathbf{1 a}$, since $\mathbf{5}$ contains a five-membered chelate ring which is more favorable than the six-membered ring in 1a. In addition, the structural data of $\mathbf{1 a}$ and $\mathbf{5}$ show no significant difference with respect to the tetrahedral nitrogen geometry so that the contribution of steric effects to the difference in $\mathrm{Cu}-\mathrm{N}$ bonding is probably negligible.

As a result of its high molecular mass $(\mathrm{fw}=2392.6)$, we were unable to reach a sufficiently high concentration of 6 in benzene to perform a successful cryoscopic molecular weight determination in this solvent. However, its ${ }^{1} \mathrm{H}$ NMR resonance patterns, although complex (Figure 3), are consistent with a nonameric structure in solution. The asymmetry of a nonameric aggregate should result in more than one $\mathrm{NMe}_{2}$ signal, and the stacking of a naphthyl ligand in the middle layer between two (top and bottom) naphthyl ligands could be expected to give rise to characteristic upfield and downfield shifts due to aromatic ring currents. This latter feature seems to be present. First, there are clearly separate patterns for two different 8-(dimethyl- 


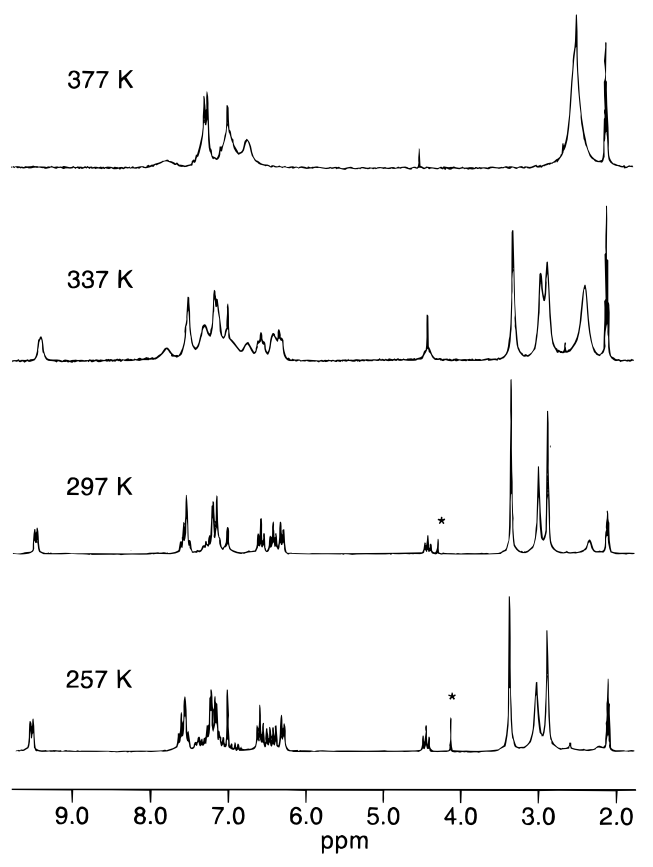

Figure 3. ${ }^{1} \mathrm{H}$ NMR spectra of 6 at variable temperatures $\left(\mathrm{C}_{7} \mathrm{D}_{8}, 200.13\right.$ $\mathrm{MHz}$ ). Asterisk indicates solvent impurity; the multiplet at $2.1 \mathrm{ppm}$ is from the solvent.

amino)naphthalene-1-thiolate ligands in a 2:1 ratio with the less intense pattern showing more widely separated multiplets than are found in the other. A very characteristic feature is that in the ${ }^{1} \mathrm{H}$ NMR spectrum of $\mathbf{6}$ there is one triplet at $4.49 \mathrm{ppm}$ arising from an aromatic proton of one arenethiolate ligand and a doublet at $9.51 \mathrm{ppm}$ arising from two arenethiolate ligands. Moreover, the less intense ligand resonance pattern is separated into a set of doublets and triplets, while the resonances of the other ligands appear as multiplets at 7.1-7.4 and 7.5-7.7 ppm.

The possibility of various diastereoisomers of $\mathbf{6}$, each with its different symmetry characteristics, is a factor that has to be considered in the full interpretation of the NMR data. The diastereoisomer encountered in the solid state (Figure 2) is expected to give rise to three different NMe signals, i.e. one singlet for the $\mathrm{NMe}_{2}$ groups in the middle layer and two singlets from the $\mathrm{NMe}_{2}$ groups of the top and bottom layers, whereas the alternative diastereoisomer can afford a maximum of six different NMe resonances.

In fact, when one examines the ${ }^{1} \mathrm{H}$ NMR spectrum of $\mathbf{6}$, one sees at least three major NMe resonances with 1:1:1 relative intensities though with different line widths, and these data are consistent with the nonameric structure as found in the solid state; i.e., we do not appear to see the alternative diastereoisomer. However, in the spectrum of $\mathbf{6}$ at $297 \mathrm{~K}$, there is a further low-intensity NMe group at $2.3 \mathrm{ppm}$, while careful examination of the aromatic region reveals the presence of at least one other arenethiolate ligand pattern pointing to the presence of a second species. The situation is therefore not straightforward, and a further complicating factor is that the NMR spectra show reversible temperature-dependent behavior. On warming of the solution, the intensity of the resonances from the second species grows and in the high-temperature limit at $377 \mathrm{~K}$ this species now dominates completely with one broad NMe resonance at $2.6 \mathrm{ppm}$ and a single arenethiolate pattern with rather broad resonances between 6.5 and $8.0 \mathrm{ppm}$. On cooling below room temperature, the patterns for $\mathbf{6}$ change little except for the virtual disappearance of the resonances associated with the peak at $2.3 \mathrm{ppm}$.

Although we believe that the broad resonances at high temperature arise from a new species (vide infra), it is worth mentioning that such broadening could potentially arise from other sources. For example, coalescence of the interconverting species which give sharp lines at low temperature would afford broad resonances that would appear at the weighted average of the individual chemical shifts; at $377 \mathrm{~K}$, the broad resonances observed are, however, clearly to higher field of expected coalescence positions (see Figure 3). Furthermore, broadened lines could also be explained by exchange of $\mathbf{6}$ with a small amount of paramagnetic species, a real possibility for these airsensitive materials at high temperatures. However, the deliberate introduction of $\mathrm{Cu}(\mathrm{II})$ ions did not afford significant line broadening.

From these data it is clear that in solution the nonameric form of $\mathbf{6}$ is in equilibrium with a far more symmetric species, and we believe that the fluxional processes occurring involve changes in $\mathrm{N} \rightarrow \mathrm{Cu}$ coordination. In this respect, it is possible that coordination of a dimethylamino group from the middle layer to a copper atom from either the top or the bottom layer, in combination with subsequent rearrangement of arenethiolate coordination and $\mathrm{Cu}_{3} \mathrm{~S}_{3}$ ring puckering within the nonameric assembly, could lead to a new species with a structure identical to that observed in the solid state in which the earlier labeled atoms $\mathrm{Cu}^{\mathrm{t}}, \mathrm{S}^{\mathrm{t}}, \mathrm{Cu}^{\mathrm{m}}, \mathrm{S}^{\mathrm{m}}, \mathrm{Cu}^{\mathrm{b}}$, and $\mathrm{S}^{\mathrm{b}}$ have now generated a new top or bottom layer; i.e., in a theoretical "fast-exchange" the aggregate would have spherical symmetry and thus only one ligand pattern in its NMR spectrum. Alternatively, the nonamer may be generating smaller symmetric aggregates $\left[\mathrm{Cu}_{3}(\mathrm{SAr})_{3}\right]$. Both ideas would be consistent with the single high-temperature pattern.

Mixed Copper Arenethiolate Aggregates $\left[\mathrm{Cu}_{3}-\right.$ $\left.(\mathbf{S A r})_{3-n}\left(\mathbf{S A r}^{\prime}\right)_{n}\right]$. The above results show that aggregates $\mathbf{5}$ and $\mathbf{6}$ undergo intramolecular fluxional processes in solution. To investigate whether interaggregate exchange between the copper arenethiolate aggregates $\mathbf{5}$ and $\mathbf{6}$ themselves occurs in solution, mixtures of these complexes (both in the solid state and in solution) were studied by both mass spectroscopy (electron impact (EI)) and ${ }^{1} \mathrm{H}$ NMR spectroscopy. The EI mass spectrum of pure 5 shows a molecular peak for the trimer $\left[\mathrm{Cu}_{3}(\mathrm{SAr})_{3}\right]$ at $m / e 647$ (calcd m/e 647) as well as signals with lower intensities arising from aggregates $\left[\mathrm{Cu}_{3}(\mathrm{SAr})_{2}\right]^{+}$and $\left[\mathrm{Cu}_{2}(\mathrm{SAr})_{2}\right]$ at $m / e 495$ and 430 , respectively (calcd m/e 495 and 430 with matching isotope patterns). This is in concert with the data from cryoscopy and ${ }^{1} \mathrm{H}$ NMR spectroscopy that give evidence for the presence of only the neutral trinuclear aggregate $\left[\mathrm{Cu}_{3}(\mathrm{SAr})_{3}\right]$.

Complex 6 does not afford a mass spectrum with any peaks of significant intensity, and we conclude that the nonameric aggregate is not volatile enough or decomposes before it enters the vapor phase. However, a sample taken from a solution containing both 5 and $\mathbf{6}$ that was evaporated to dryness shows a mass spectrum which is significantly different from that obtained from pure 5. Superimposed on the spectrum for $\mathbf{5}$, there are now new signals at $m / e \quad 697$ and 748 with matching isotope patterns arising from the mixed 2:1 and 1:2 aggregates $\left[\mathrm{Cu}_{3}(\mathrm{SAr})_{2}\left(\mathrm{SAr}^{\prime}\right)\right]$ and $\left[\mathrm{Cu}_{3}(\mathrm{SAr})\left(\mathrm{SAr}^{\prime}\right)_{2}\right]$ (calcd m/e 697 and 747). The spectrum obtained from an intimate mixture of solid $\mathbf{5}$ and $\mathbf{6}$ also shows these new signals.

These results lead us to conclude that the neutral aggregates $\left[\mathrm{Cu}_{3}(\mathrm{SAr})_{3}\right](5)$ and $\left[\mathrm{Cu}_{9}(\mathrm{SAr})_{9}\right](\mathbf{6})$ can undergo interaggregate ligand exchange and that stable mixed trinuclear aggregates $\left[\mathrm{Cu}_{3}(\mathrm{SAr})_{2}\left(\mathrm{SAr}^{\prime}\right)\right]$ and $\left[\mathrm{Cu}_{3}(\mathrm{SAr})\left(\mathrm{SAr}^{\prime}\right)_{2}\right]$ are possible. Similar experiments have also been performed with other copper arenethiolates with similar results. ${ }^{30}$ For example, mass spectra

(30) van Klaveren, M.; Eijkelkamp, D. J. F. M.; Lambert, F.; Grove, D. M.; van Koten, G. To be published. 
of 1:1 combinations of trinuclear complexes $\left[\mathrm{Cu}_{3}\left(\mathrm{SC}_{6} \mathrm{H}_{4} \mathrm{CH}_{2}-\right.\right.$ $\left.\left.\mathrm{NMe}_{2}-2\right)_{3}\right](\mathbf{1 a})$ and $\left[\mathrm{Cu}_{3}\left(\mathrm{SC}_{6} \mathrm{H}_{4} \mathrm{CH}(\mathrm{Me}) \mathrm{NMe}_{2}-2\right)_{3}\right](\mathbf{1 b})$ as well as of $\left[\mathrm{Cu}_{3}\left\{\mathrm{SC}_{6} \mathrm{H}_{4}\left((R)-\mathrm{CH}(\mathrm{Me}) \mathrm{NMe}_{2}\right)-2\right\}_{3}\right](R-\mathbf{1 b})$ and $\left[\mathrm{Cu}_{3}-\right.$ $\left.\left\{\mathrm{SC}_{6} \mathrm{H}_{4}\left((S)-\mathrm{CH}(\mathrm{Me}) \mathrm{NMe}_{2}\right)-2\right\}_{3}\right](S-\mathbf{1 b})$ show the presence of statistical mixtures of mixed aggregates.

The scrambling of anionic arenethiolate ligands between aggregates could occur either via anionic species such as $\left[\mathrm{Cu}_{3}(\mathrm{SAr})_{3}\left(\mathrm{SAr}^{\prime}\right)\right]^{-}$or via self-assembly of smaller species such as mononuclear $[\mathrm{Cu}(\mathrm{SAr})]$ units. Since the pure aggregates $\left[\mathrm{Cu}_{3}(\mathrm{SAr})_{3}\right]$ as well as the mixed aggregates appear to coexist in solution, we believe that they have comparable thermodynamical stabilities.

Reaction of 5 and 6 with Organocopper Aggregates. A final aspect of this study has been to investigate whether assembly of new aggregates from $\mathrm{Cu}(\mathrm{SAr})$ and $\mathrm{CuR}$ units is possible. The reaction of [8-(dimethylamino)naphthalene-1thiolato]copper(I) (6) with (3,3-dimethylbutynyl)copper in a 2:1 ratio (based on monomeric $\mathrm{Cu}$ units) results in the formation of the hexanuclear 2:4 alkynyl(arenethiolato)copper(I) aggregate $\left[\mathrm{Cu}_{3}\left(\mathrm{~S}-1-\mathrm{C}_{10} \mathrm{H}_{6} \mathrm{NMe}_{2}-8\right)_{2}\left(\mathrm{C} \equiv \mathrm{C}^{\mathrm{t}} \mathrm{Bu}\right)\right]_{2}$ (9) (eq 1). When this

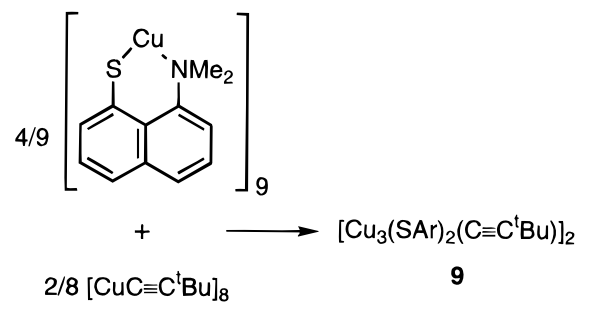

reaction is performed with a different ratio of $\mathbf{6}:\left[\mathrm{CuC} \equiv \mathrm{C}^{t} \mathrm{Bu}\right]$, the same product (i.e. 9) is still isolated and unreacted 6 or $\left[\mathrm{CuC} \equiv \mathrm{C}^{\mathrm{t}} \mathrm{Bu}\right]$ remains in the reaction mixture. Aggregate $\mathbf{9}$ is isolated as an orange solid that is insoluble in common organic solvents and only slightly soluble in polar or aromatic solvents such as THF or benzene, but it can be readily dissolved in pyridine.

A similar reaction of 6 with mesitylcopper, $[\mathrm{Cu}(\mathrm{Mes})]_{5}$, in a 1:1 ratio (based on $\mathrm{Cu}$ ) affords the mixed mesityl(arenethiolato)copper aggregate $\left[\mathrm{Cu}_{2}\left(\mathrm{~S}-1-\mathrm{C}_{10} \mathrm{H}_{6} \mathrm{NMe}_{2}-8\right)(\mathrm{Mes})\right]_{n}(\mathbf{1 0})$ in which the arenethiolate and mesityl ligands are present in a $1: 1$ ratio (eq 2). As was the case for the synthesis of $\mathbf{9}$, performing the

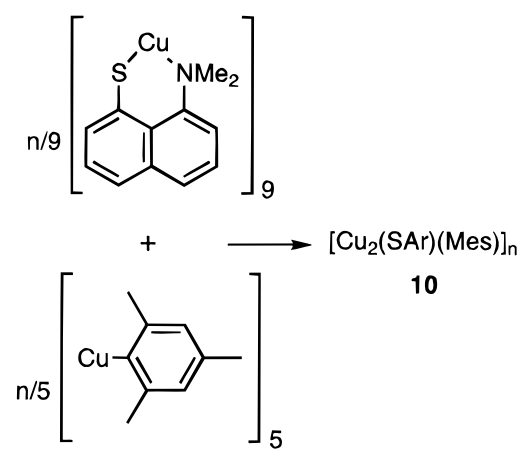

reaction in a different stoichiometry still leads to the same product (i.e. 10), although it is obtained in a lower yield.

Mixed aggregate $\mathbf{1 0}$ is a yellow, slightly air-sensitive solid that is insoluble in pentane or hexane, though it is readily soluble in common organic solvents, and in these respects it is similar to known $\left[\mathrm{Cu}_{4}\left(\mathrm{SC}_{6} \mathrm{H}_{4} \mathrm{CH}_{2} \mathrm{NMe}_{2}-2\right)_{2}(\mathrm{Mes})_{2}\right](8)$. Unfortunately, single crystals of $\mathbf{1 0}$ suitable for X-ray structure determination have not been obtained.

Similar reactions of trimeric $\mathbf{5}$ with organocopper aggregates have also been performed, but it is not clear whether mixed organo(arenethiolato)copper(I) aggregates are formed or not;

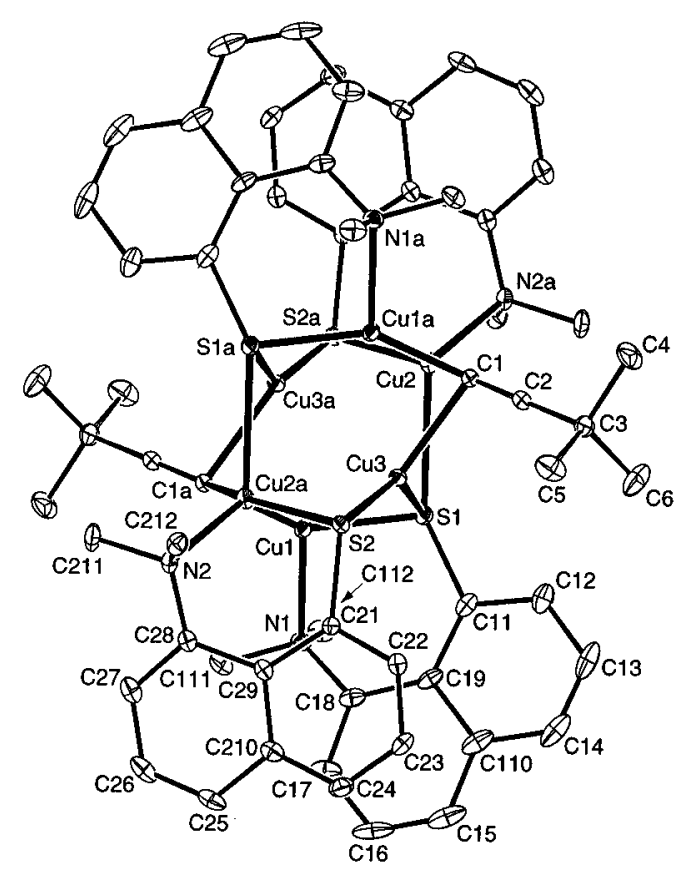

Figure 4. ORTEP drawing (50\% probability level) of hexanuclear $\left[\mathrm{Cu}_{3}\left(\mathrm{~S}-1-\mathrm{C}_{10} \mathrm{H}_{6} \mathrm{NMe}_{2}-8\right)_{2}\left(\mathrm{C} \equiv \mathrm{C}^{t} \mathrm{Bu}\right)\right]_{2}(9)$ (excluding the hydrogen atoms) with the adopted atom-labeling scheme.

variable-temperature ${ }^{1} \mathrm{H}$ NMR measurements on these reaction mixtures afford spectra which are very similar to those of the starting materials. As briefly outlined above, the 2-(dimethylamino)benzenethiolato ligand is not a good NMR probe since $\mathrm{Cu}-\mathrm{N}$ coordination is probably weak and the $\mathrm{NMe}_{2}$ substituent is therefore not likely to be a stable stereogenic grouping that can function as a probe of dissymmetry in aggregates that may be formed.

Structure of 9 in the Solid State. To obtain more structural data on the alkynyl(arenethiolato)copper(I) aggregate $\left[\mathrm{Cu}_{3}(\mathrm{~S}\right.$ $\left.\left.1-\mathrm{C}_{10} \mathrm{H}_{6} \mathrm{NMe}_{2}-8\right)_{2}\left(\mathrm{C} \equiv \mathrm{C}^{\mathrm{t}} \mathrm{Bu}\right)\right]_{2}(\mathbf{9})$, an $\mathrm{X}$-ray structure determination was carried out (Figure 4). Selected geometrical details of 9 are collected in Table 4.

Complex 9 is a hexanuclear aggregate comprising two identical symmetry-related $\left[\mathrm{Cu}_{3}(\mathrm{SAr})_{2}\left(\mathrm{C} \equiv \mathrm{C}^{t} \mathrm{Bu}\right)\right]$ units which are based on a cyclohexane-like six-membered $\mathrm{Cu}_{3} \mathrm{~S}_{2} \mathrm{C}$ ring. These $\mathrm{Cu}_{3} \mathrm{~S}_{2} \mathrm{C}$ rings $(\mathrm{C} 1 \mathrm{a}, \mathrm{Cu} 1, \mathrm{~S} 1, \mathrm{Cu} 3, \mathrm{~S} 2, \mathrm{Cu} 2 \mathrm{a}$ and $\mathrm{C} 1$, $\mathrm{Cu} 1 \mathrm{a}, \mathrm{S} 1 \mathrm{a}, \mathrm{Cu} 3 \mathrm{a}, \mathrm{S} 2 \mathrm{a}, \mathrm{Cu} 2)$ are in a slightly twisted boat conformation, and the "bow and stern" positions of this boat conformation are defined by a copper atom $\mathrm{Cu} 3$ (and $\mathrm{Cu} 3 \mathrm{a}$ ) and the $\mathrm{C}_{\alpha}$ atom of the 3,3-dimethylbutynyl entities C1a (and C1). In this description, the aryl rings of the arenethiolate ligands are positioned axially with respect to the corresponding $\mathrm{Cu}_{3} \mathrm{~S}_{2} \mathrm{C}$ rings. The dimeric hexanuclear structure is brought about by two inter-ring interactions; namely, an interaction of the alkynyl $\mathrm{C}_{\alpha}$ atom (C1) with a copper atom (Cu3) of the opposite $\mathrm{Cu}_{3} \mathrm{~S}_{2} \mathrm{C}$ unit $(\mathrm{Cu} 3-\mathrm{C} 12.186(3) \AA)$ and an interaction of sulfur atom $\mathrm{S} 1$ with a copper atom $(\mathrm{Cu} 2)$ in the other ring (Cu2-S1 2.7761(8) ^).

The bonding description within each $\left[\mathrm{Cu}_{3}(\mathrm{SAr})_{2}\left(\mathrm{C} \equiv \mathrm{C}^{\mathrm{t}} \mathrm{Bu}\right)\right]$ unit is that both arenethiolate ligands $\mathrm{S}$-bridge two copper atoms $(\mathrm{Cu} 1-\mathrm{S} 1, \mathrm{Cu} 2 \mathrm{a}-\mathrm{S} 2, \mathrm{Cu} 3-\mathrm{S} 1$, and $\mathrm{Cu} 3-\mathrm{S} 2$ are 2.2001(8),

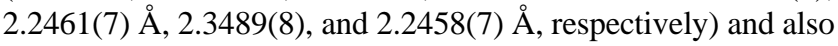
intramolecularly coordinate with the $\mathrm{N}$-donor function to one copper atom in this unit (Cu1-N1 2.160(2); Cu2a-N2 2.138(2) $\AA)$. These $\mathrm{Cu}-\mathrm{N}$ distances are significantly shorter than those in the parent complex 6, in which they average $2.37 \AA$, and they point to a stronger $\mathrm{N} \rightarrow \mathrm{Cu}$ coordination in 9 . The angles $\mathrm{Cu} 1-\mathrm{S} 1-\mathrm{Cu} 3$ and $\mathrm{Cu} 3-\mathrm{S} 2-\mathrm{Cu} 2 \mathrm{a}$ are 69.42(3) and 75.69(2) ${ }^{\circ}$, 
Table 4. Selected Geometrical Details of $\left[\mathrm{Cu}_{6}\left(1-\mathrm{SC}_{10} \mathrm{H}_{6} \mathrm{NMe}_{2}-8\right)_{4}\left(\mathrm{C} \equiv \mathrm{C}{ }^{\mathrm{t} B u}\right)_{2}\right](9)^{a}$

\begin{tabular}{|c|c|c|c|c|c|}
\hline \multicolumn{6}{|c|}{ Bond Lengths (§) } \\
\hline $\mathrm{Cu} 1-\mathrm{S} 1$ & $2.2001(8)$ & $\mathrm{Cu} 2 \mathrm{a}-\mathrm{S} 2$ & $2.2461(7)$ & & \\
\hline $\mathrm{Cu} 3-\mathrm{S} 1$ & $2.3489(8)$ & $\mathrm{Cu} 3-\mathrm{S} 2$ & $2.2458(7)$ & $\mathrm{Cu} 2-\mathrm{S} 1$ & $2.7761(8)$ \\
\hline $\begin{array}{l}\mathrm{Cu} 1-\mathrm{C} 1 \mathrm{a} \\
\mathrm{Cu} 2 \mathrm{a}-\mathrm{C} 1 \mathrm{a} \\
\mathrm{Cu} 3-\mathrm{C} 1\end{array}$ & $\begin{array}{l}1.965(3) \\
1.970(3) \\
2.186(3)\end{array}$ & & & $\mathrm{Cu} 3-\mathrm{C} 2$ & $2.790(3)$ \\
\hline $\mathrm{Cu} 1-\mathrm{N} 1$ & $2.160(2)$ & $\mathrm{Cu} 2 \mathrm{a}-\mathrm{N} 2$ & $2.138(2)$ & & \\
\hline $\begin{array}{l}\mathrm{Cu} 1 \cdots \mathrm{Cu} 2 \mathrm{a} \\
\mathrm{Cu} 1 \cdots \mathrm{Cu} 3\end{array}$ & $\begin{array}{l}2.4668(5) \\
2.5931(6)\end{array}$ & $\begin{array}{l}\mathrm{Cu} 1 \cdots \mathrm{Cu} 3 \mathrm{a} \\
\mathrm{Cu} 2 \cdots \mathrm{Cu} 3\end{array}$ & $\begin{array}{l}2.6866(6) \\
2.5353(5)\end{array}$ & & \\
\hline $\mathrm{S} 1-\mathrm{C} 11$ & $1.783(3)$ & $\mathrm{S} 2-\mathrm{C} 21$ & $1.787(3)$ & $\mathrm{C} 1-\mathrm{C} 2$ & $1.222(4)$ \\
\hline $\begin{array}{l}\mathrm{Cu} 1-\mathrm{S} 1-\mathrm{Cu} 3 \\
\mathrm{Cu} 2 \mathrm{a}-\mathrm{S} 2-\mathrm{Cu} 3\end{array}$ & $\begin{array}{l}69.42(3) \\
75.69(2)\end{array}$ & $\begin{array}{l}\quad \text { Bond Ar } \\
\mathrm{Cu} 1-\mathrm{S} 1-\mathrm{Cu} 2 \\
\mathrm{Cu} 2-\mathrm{S} 1-\mathrm{Cu} 3\end{array}$ & $\begin{array}{l}94.42(3) \\
58.59(2)\end{array}$ & & \\
\hline $\mathrm{Cu} 1 \mathrm{a}-\mathrm{C} 1-\mathrm{Cu} 2$ & $77.64(10)$ & $\begin{array}{l}\mathrm{Cu} 1 \mathrm{a}-\mathrm{C} 1-\mathrm{Cu} 3 \\
\mathrm{Cu} 2-\mathrm{C} 1-\mathrm{Cu} 3\end{array}$ & $\begin{array}{l}80.46(9) \\
74.97(9)\end{array}$ & $\mathrm{C} 1-\mathrm{C} 2-\mathrm{C} 3$ & 179.1(3) \\
\hline $\begin{array}{l}\mathrm{S} 1-\mathrm{Cu} 1-\mathrm{N} 1 \\
\mathrm{~S} 1-\mathrm{Cu} 1-\mathrm{C} 1 \mathrm{a}\end{array}$ & $\begin{array}{r}91.96(7) \\
149.68(8)\end{array}$ & $\begin{array}{l}\mathrm{S} 2-\mathrm{Cu} 2 \mathrm{a}-\mathrm{N} 2 \\
\mathrm{~S} 2 \mathrm{a}-\mathrm{Cu} 2-\mathrm{C} 1\end{array}$ & $\begin{array}{r}90.24(7) \\
152.07(8)\end{array}$ & $\begin{array}{l}\mathrm{S} 1-\mathrm{Cu} 3-\mathrm{S} 2 \\
\mathrm{~S} 1-\mathrm{Cu} 3-\mathrm{C} 1\end{array}$ & $\begin{array}{l}138.64(3) \\
105.24(7)\end{array}$ \\
\hline $\mathrm{N} 1-\mathrm{Cu} 1-\mathrm{C} 1 \mathrm{a}$ & $115.80(10)$ & $\mathrm{N} 2 \mathrm{a}-\mathrm{Cu} 2-\mathrm{C} 1$ & $111.58(10)$ & $\mathrm{S} 2-\mathrm{Cu} 3-\mathrm{C} 1$ & $114.82(7)$ \\
\hline
\end{tabular}

${ }^{a}$ The estimated standard deviations are given in parentheses. Symmetry operation: $-x,-y,-z$.

respectively, and these acute angles seem to reflect a twoelectron three-center $(2 \mathrm{e}-3 \mathrm{c})$ bonding of the arenethiolate ligands in 9. Within the $\mathrm{Cu}_{3} \mathrm{~S}_{2} \mathrm{C}$ ring, the (alkynyl) $\mathrm{C}_{\alpha}$ atom $(\mathrm{C} 1)$ bridges the two copper atoms $\mathrm{Cu} 1 \mathrm{a}$ and $\mathrm{Cu} 2$ with $\mathrm{Cu}-\mathrm{C}$ distances of $1.965(3)$ and $1.970(3) \AA$, respectively.

As a result of this bonding, there are three different copper atom geometries. First, copper atom $\mathrm{Cu} 1$ has a distorted trigonal planar geometry arising from ligation by one sulfur, one nitrogen, and one alkynyl- $\mathrm{C}_{\alpha}$ atom from the same $\mathrm{Cu}_{3} \mathrm{~S}_{2} \mathrm{C}$ unit. The second copper atom $\mathrm{Cu} 2$ has a similar ligation by one sulfur, one nitrogen, and one alkynyl- $\mathrm{C}_{\alpha}$ atom from the same $\mathrm{Cu}_{3} \mathrm{~S}_{2} \mathrm{C}$ unit, but due to the slight twist of the boat conformation, it also interacts with a sulfur atom from the opposite $\mathrm{Cu}_{3} \mathrm{~S}_{2} \mathrm{C}$ unit and so attains a distorted tetrahedral surrounding. Finally, copper atom $\mathrm{Cu} 3$ has an almost trigonal planar geometry that results from bonding to two sulfur atoms within the same $\mathrm{Cu}_{3} \mathrm{~S}_{2} \mathrm{C}$ ring and with the (alkynyl) $\mathrm{C}_{\alpha}$ of the opposite ring.

Structure of 9 and 10 in Solution. A cryoscopic molecular weight determination of $\mathbf{9}$ in benzene was unfortunately not successful as a result of the low solubility of $\mathbf{9}$ in this solvent. The ${ }^{1} \mathrm{H}$ NMR spectrum of 9 in either benzene- $d_{6}$ or the coordinating solvent pyridine- $d_{5}$ is significantly different from that of nonameric $\mathbf{6}$ and essentially temperature independent in the latter solvent. For example, the ${ }^{1} \mathrm{H}$ NMR spectrum of the alkynyl(arenethiolato)copper(I) aggregate 9 in pyridine- $d_{5}$ (297 $\mathrm{K})$ consists of one singlet at $1.25 \mathrm{ppm}$ from the 3,3-dimethylbutynyl protons, a broadened singlet at $2.60 \mathrm{ppm}$ from the arenethiolate $\mathrm{NMe}_{2}$ protons, and characteristic multiplet resonance patterns for the naphthyl protons. To explain this simple spectrum, we believe that $\mathbf{9}$ exists in solution as a hexanuclear aggregate similar to the solid state structure with symmetric $\mathrm{Cu}_{3} \mathrm{~S}_{2} \mathrm{C}$ rings in which the arenethiolate ligands are equivalent. On the basis of these data, one cannot exclude, however, the possibility of 9 existing as a trinuclear species $\left[\mathrm{Cu}_{3}(\mathrm{SAr})_{2}-\right.$ $\left.\left(\mathrm{C} \equiv \mathrm{C}^{\mathrm{t}} \mathrm{Bu}\right)\right]$ in solution.

The ${ }^{1} \mathrm{H}$ NMR spectrum of mesityl(arenethiolato)copper(I) aggregate $\left[\mathrm{Cu}_{2}\left(\mathrm{~S}-1-\mathrm{C}_{10} \mathrm{H}_{6} \mathrm{NMe}_{2}-8\right)(\mathrm{Mes})\right]_{n}(\mathbf{1 0})$ in benzene- $d_{6}$ is, as also seen above for hexanuclear $\mathbf{9}$, significantly different from that of nonameric $\mathbf{6}$. The spectra of $\mathbf{1 0}$ in toluene- $d_{8}$ are temperature dependent, and a detailed interpretation of the room temperature spectrum has not proved possible. However, at 333 $\mathrm{K}$ the integrals are consistent with a 1:1 naphthyl to mesityl ratio and there is just one pattern for each ligand type. Therefore, $\mathbf{1 0}$ is probably a mixed aggregate of the type

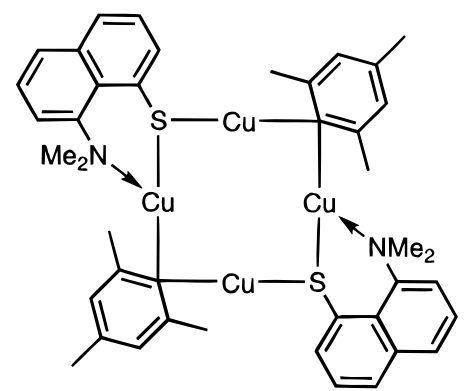

Figure 5. Proposed structure for mesityl(arenethiolato)copper(I) aggregate $\mathbf{1 0 .}$

$\left[\mathrm{Cu}_{2}(\mathrm{SAr})(\mathrm{Mes})\right]_{n}(n \geq 1)$ which possesses high symmetry. The fluxional behavior of $\mathbf{1 0}$ is clearly related to that reported earlier for the mixed organo(arenethiolato)copper aggregate $\mathbf{8}$ that has a butterfly $\mathrm{Cu}_{4} \mathrm{~S}_{2} \mathrm{C}_{2}$ core structure. ${ }^{12}$ On the basis of these results, we propose a structure for $\mathbf{1 0}$ (similar to $\mathbf{8}$ ) that comprises a tetranuclear copper array, two arenethiolate ligands, and two mesityl groups, thus forming a central $\mathrm{Cu}-\mathrm{S}-\mathrm{Cu}-$ $\mathrm{C}-\mathrm{Cu}-\mathrm{S}-\mathrm{Cu}-\mathrm{C}$ eight-membered ring (Figure 5).

The two arenethiolate ligands (and two mesityl groups) in this assembly are positioned on opposite sides of the $\mathrm{Cu}_{4}$ array, and nitrogen coordination of these arenethiolates, which is likely to occur, is to opposite copper centers. An alternative structure for $\mathbf{1 0}$ is an isomeric tetranuclear aggregate in which the two arenethiolates (and the two mesityl groups) are on adjacent (cis) sides of the $\mathrm{Cu}_{4}$ array, resulting in a $\mathrm{Cu}-\mathrm{S}-\mathrm{Cu}-\mathrm{S}-\mathrm{Cu}-\mathrm{C}-$ $\mathrm{Cu}-\mathrm{C}$ eight-membered ring. Both structures are in agreement with the ${ }^{1} \mathrm{H}$ NMR data for $\mathbf{1 0}$.

\section{Discussion}

Synthesis of Copper(I) Arenethiolates 5 and 6. The first aspect of this paper is the way by which complexes 5 and $\mathbf{6}$ have been obtained from a pure trimethylsilyl arylthioether and $\mathrm{CuCl}$. Interestingly, attempts to prepare copper thiophenolate $(\mathrm{CuSPh})$ in an analogous way by reacting $\mathrm{Me}_{3} \mathrm{SiSPh}$ with equimolar amounts of $\mathrm{CuCl}$ failed. This observation indicates that the presence of an ortho substituent on the aromatic ring that has potential for coordination is crucial for the success of this synthetic method. Since it is known that substitutions on silicon are often second order in the nucleophile, ${ }^{31}$ we suggest that intramolecular coordination of the amine donor to silicon assists the attack of the nucleophilic $\mathrm{Cl}$ anions at the surface of 


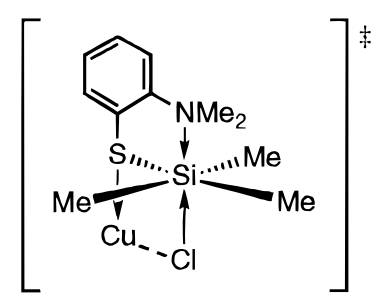

Figure 6. Proposed intermediate in the synthesis of copper arenethiolate $\mathbf{5}$ (and $\mathbf{6}$ ).

$\mathrm{CuCl}$. This would result in the formation of a 6-coordinate silicon intermediate (illustrated for 5 in Figure 6). The anchimeric assistance of a well-positioned nucleophile, i.e. intramolecular chelation, in substitution processes at silicon centers has been reported before. ${ }^{31 \mathrm{a}-\mathrm{d}}$ Alternatively, the chelating $\mathrm{NMe}_{2}$ group could assist in positioning the copper ion near the sulfur atom, activating it as a leaving group for the substitution reaction.

In our chemistry, the (arenethiolato)copper(I) species formed in the above reactions assemble through $\mathrm{S}$ and $\mathrm{N}$ coordination to a multinuclear copper arenethiolate aggregate. This results in the formation of a copper arenethiolate trimer in the case of 5 and in the formation of a nonamer in the case of $\mathbf{6}$.

Structures in the Solid State. The second aspect of this study is the role that the arenethiolate backbone, which connects the sulfur and nitrogen atoms, plays in the assembly of $[\mathrm{Cu}(\mathrm{SAr})]$ units to larger aggregates. In copper chemistry, the use of arenethiolates with the potential to form six-membered chelates via intramolecular coordination has so far resulted in trimeric structures. Therefore, it is surprising that copper arenethiolate $\mathbf{6}$ is nonameric, and in fact, this is the first nonameric copper thiolate structure of any type. It would appear not only that the chelate size and the Lewis-base strength of the chelating atom are important but also that the rigidity of the ligand backbone does play a significant role in determining the final aggregate structure. A comparative examination of some structures allows us to analyze those aspects that primarily affect the assembly of $\mathrm{Cu}(\mathrm{SAr})$ units.

In trimeric aggregates such as $\left[\mathrm{Cu}_{3}\left(\mathrm{SC}_{6} \mathrm{H}_{4} \mathrm{NMe}_{2}-2\right)_{3}\right](5)$ and $\left[\mathrm{Cu}\left\{\mathrm{SC}_{6} \mathrm{H}_{4}\left(R-\mathrm{CH}(\mathrm{Me}) \mathrm{NMe}_{2}\right)-2\right\}\right]_{3}$ (1b), ${ }^{2 \mathrm{a}}$ one finds that the $\mathrm{Cu}-\mathrm{S}$ distance within the five- and six-membered chelate rings is longer than the $\mathrm{Cu}-\mathrm{S}$ distance between two neighboring $\mathrm{Cu}$ (SAr) units. One of the most noticeable differences between these two structures is that the $\mathrm{Cu}-\mathrm{N}$ distance of 2.170(4) $\AA$ in $\mathbf{5}$ is almost $0.1 \AA$ longer than that in $\mathbf{1 b}(2.077(7) \AA)$, and this seems to indicate there is slightly weaker nitrogen to copper coordination in $\mathbf{5}$ than in $\mathbf{1 b}$ (vide supra). Apparently, the overall trimeric structure is not sensitive to the chelate ring size.

In the structures of $\mathbf{5}$ and $\mathbf{1 b}$, the acute $\mathrm{Cu}-\mathrm{S}-\mathrm{Cu}$ angles of 75.18(4) (5) and $79.63(7)^{\circ}(\mathbf{1 b})$ together with the $\mathrm{Cu} \cdots \mathrm{Cu}$ distances of 2.6962(8) and 2.828(1) $\AA$, respectively, are fully in concert with a two-electron three-center (2e-3c) arenethiolate bonding interpretation. ${ }^{2 \mathrm{a}, 12}$ However, there is a significant difference between $\mathbf{5}$ and $\mathbf{1 b}$ in the hybridization geometry of the sulfur atoms in these bridges. For example, in $\mathbf{5}$ the angle $\mathrm{Cu} 1-\mathrm{S} 1-\mathrm{C} 1$ (to neighboring chelate) of $108.3(1)^{\circ}$ seems

(31) (a) Corriu, R. J. P.; Guérin, C. Adv. Organomet. Chem. 1982, 20 , 265-312. (b) Corriu, R. J. P. Pure Appl. Chem. 1988, 60, 99-106. (c) Chuit, C.; Corriu, R. J. P.; Reyé, C. J. Organomet. Chem. 1988, 358, 57-66. (d) Boudin, A.; Cerveau, G.; Chuit, C.; Corriu, R. J. P.; Reyé, C. Organometallics 1988, 7, 1165-1171. (e) Corriu, R. J. P.; Guérin, C.; Henner, B. J. L.; Wang, Q. Organometallics 1991, 10, 2297-2303. (f) Corriu, R. J. P.; Guérin, C.; Henner, B. J. L.; Wang, Q. Organometallics 1991, 10, 3200-3205. (g) Corriu, R. J. P.; Guérin, C.; Henner, B. J. L.; Wang, Q. Organometallics 1991, 10, 35743581. indicative for an $\mathrm{sp}^{3}$ geometry of the sulfur atom, whereas the angle $\mathrm{Cu} 1 \mathrm{a}-\mathrm{S} 1-\mathrm{C} 1$ (within chelate) of $97.5(1)^{\circ}$ might be indicative for a different hybridization. It seems likely that this anomaly arises from strain in the five-membered chelate ring, since this difference in $\mathrm{Cu}-\mathrm{S}-\mathrm{C}$ angles is absent in the structures of the complexes $\mathbf{1 b}$ and $\left[\mathrm{Cu}\left\{\mathrm{SC}_{6} \mathrm{H}_{4}\left(\mathrm{CH}_{2} \mathrm{~N}(\mathrm{Me}) \mathrm{CH}_{2}-\right.\right.\right.$ $\left.\left.\left.\mathrm{CH}_{2} \mathrm{OMe}\right)-2\right\}\right]_{4}(\mathbf{3 a})^{3}$ which have six-membered chelate rings. The geometry of sulfur is thus dependent on the ligand backbone. With respect to the $\mathrm{Cu}_{3} \mathrm{~S}_{3}$ cyclohexane-like cores in $\mathbf{5}$ and $\mathbf{1 b}$, it must be noted that the puckering in the former, which has five-membered chelate rings, is somewhat less pronounced than that in $\mathbf{1 b}$, which has six-membered chelate rings. This can be quantified by geometrical parameters:

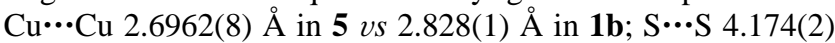
$\AA$ in $\mathbf{5}$ vs $3.977(3) \AA$ in $\mathbf{1 b} ; \mathrm{Cu}-\mathrm{S}-\mathrm{Cu} 75.18(4)^{\circ}$ in $\mathbf{5}$ vs $79.63(7)^{\circ}$ in $\mathbf{1 b} ; \mathrm{S}-\mathrm{Cu}-\mathrm{S} 141.58(4)^{\circ}$ in $\mathbf{5}$ vs $128.44(8)^{\circ}$ in $\mathbf{1 b}$.

These observations that the ligand backbone has an important influence on the sulfur geometry and on the structure of the $\mathrm{Cu}_{3} \mathrm{~S}_{3}$ unit are reinforced by an examination of the structure of nonameric 6. In this complex, the angles $\mathrm{Cu}-\mathrm{S}-\mathrm{C}$ (within chelate) and $\mathrm{Cu}-\mathrm{S}-\mathrm{C}$ (to neighboring chelate within either top or bottom layer) differ by $15^{\circ}$ as a result of the backbone rigidity of the 8-(dimethylamino)naphthalene-1-thiolato ligand. The $\mathrm{Cu}_{3} \mathrm{~S}_{3}$ ring puckering in $\mathbf{6}$ is more difficult to address, because eight of these units can be identified. However, while the $\mathrm{Cu}_{3} \mathrm{~S}_{3}$ side faces of the $\mathrm{Cu}_{9} \mathrm{~S}_{9}$ core are almost nonpuckered as a result of the almost linear geometry of the three $\mathrm{Cu}$ atoms of the middle layer, the top and bottom $\mathrm{Cu}_{3} \mathrm{~S}_{3}$ faces are more flattened than the $\mathrm{Cu}_{3} \mathrm{~S}_{3}$ core in $\mathbf{5}$.

It is known that the aggregation state found in copper(I) arenethiolate structures with intramolecular coordination is often a multiple of 3 ; i.e., one finds $\mathrm{Cu}_{3}(\mathrm{SAr})_{3},{ }^{2} \mathrm{Cu}_{6}(\mathrm{SAr})_{6},{ }^{4}$ and $\mathrm{Cu}_{9}(\mathrm{SAr})_{9}$ aggregates. Steric bulk within a $\mathrm{Cu}(\mathrm{SAr})$ unit may lead to expansion to higher (different) aggregation states, and it has been suggested that the tetrameric copper arenethiolate $\left[\mathrm{Cu}_{4}\left\{\mathrm{SC}_{6} \mathrm{H}_{4}\left(\mathrm{CH}_{2} \mathrm{~N}(\mathrm{Me}) \mathrm{CH}_{2} \mathrm{CH}_{2} \mathrm{OMe}\right)-2\right\}_{4}\right]$ (3a) is derived from the basic $\mathrm{Cu}_{3}(\mathrm{SAr})_{3}$ structure, which in this case is disfavored due to the bulk of the $\mathrm{CH}_{2} \mathrm{CH}_{2} \mathrm{OMe}$ substituent. ${ }^{3}$

Copper arenethiolates without intramolecular coordination can adopt various aggregation states which are not necessarily a multiple of 3 and which may also be anionic. Examples of such complexes include neutral $\mathrm{L}_{3} \mathrm{Cu}(\mathrm{SAr}),{ }^{6 \mathrm{a}} \mathrm{L}_{4} \mathrm{Cu}_{2}(\mathrm{SAr})_{2}$, $\mathrm{L}_{4} \mathrm{Cu}_{4}(\mathrm{SAr})_{4},{ }^{6 e}$ and $\mathrm{Cu}_{12}(\mathrm{SAr})_{12},{ }^{5}$ as well as the anionic dithiolate species $\left[\mathrm{Cu}_{4}\left(o-\left(\mathrm{SCH}_{2}\right)_{2} \mathrm{C}_{6} \mathrm{H}_{4}\right)_{3}\right]^{2-}$ 6f and $\left[\mathrm{Cu}_{8}\left(\mathrm{~S}_{2} \mathrm{CR}\right)_{6}\right]^{4-6 \mathrm{~g}}$ and the anionic alkane and benzenethiolate complexes $\left[\mathrm{Cu}_{5}(\mathrm{SR})_{6}\right]^{-6 \mathrm{~h}}$ and $\left[\mathrm{Cu}_{4}(\mathrm{SR})_{6}\right]^{2-}$ (for a complete formulation: see references) ${ }^{6 \mathrm{j}, \mathrm{k}}$ In most of these structures, six-membered $\mathrm{Cu}_{3} \mathrm{~S}_{3}$ rings are present though sometimes eight-membered $\mathrm{Cu}_{4} \mathrm{~S}_{4}$ rings are encountered. This indicates that the six-membered $\mathrm{Cu}_{3} \mathrm{~S}_{3}$ ring is a stable building block in copper arenethiolate structures and that the expansion of these $\mathrm{Cu}_{3}(\mathrm{SAr})_{3}$ structures to higher non3-fold aggregates is determined by special factors such as ligand rigidity and corresponding chelate ring flexibility in combination with steric bulk and the presence of auxiliary donor ligands.

The expansion of the $\mathrm{Cu}_{n} \mathrm{~S}_{n}$ core ( $n$ is a multiple of 3 ) is visualized in Chart 2. Interestingly, the largest reported copper arenethiolate aggregate, the dodecameric [o-(trimethylsilyl)benzenethiolato]copper(I) aggregate $\left[\mathrm{Cu}_{12}\left(\mathrm{SC}_{6} \mathrm{H}_{4} \mathrm{SiMe}_{3}-2\right)_{12}\right]$ (11),${ }^{5}$ is a "multiple of 3 " structure but lacks intramolecular coordination. Thus, the presence of intramolecular coordination seems to be of less importance in large structures than in smaller structures. This can also be observed in the nonameric structure of $\mathbf{6}$, as only six of the available nine Lewis bases are involved in intramolecular coordination. 
Chart 2. Basic Structures of $\mathrm{Cu}(\mathrm{I})$ Arenethiolates: "Multiple of 3" Aggregation States
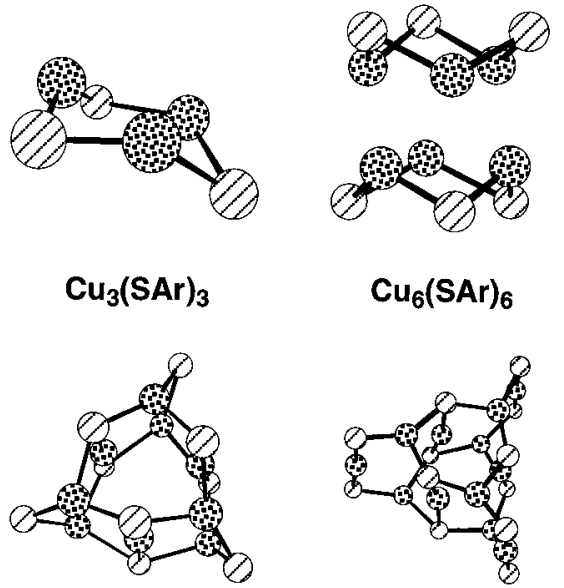

$\mathrm{Cu}_{9}(\mathrm{SAr})_{9}$

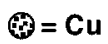

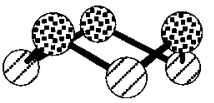

$\mathrm{Cu}_{6}(\mathrm{SAr})_{6}$

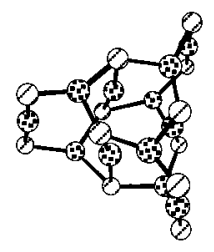

$\mathrm{Cu}_{12}(\mathrm{SAr})_{12}$

$\theta=\mathrm{S}$
In a simple description, these "multiple of 3 " aggregates can be seen to arise from interaction of the sulfur lone pairs of one $\mathrm{Cu}_{3} \mathrm{~S}_{3}$ unit with the copper atoms from a second $\mathrm{Cu}_{3} \mathrm{~S}_{3}$ unit. However, as is depicted in Chart 2, the X-ray structures of trimeric, hexameric, nonameric, and dodecameric copper arenethiolates have geometries in which the sulfur atoms of the $\mathrm{Cu}_{3} \mathrm{~S}_{3}$ units are positioned away from each other on the outside of the molecules. This means that the sulfur lone pairs (electron density) are pointing away from the center of the cage with the (nucleophilic) copper sites on the inside, and this is a logical positioning on the basis of steric and repulsive interactions. Therefore a more appropriate and more accurate description of these aggregates requires the involvement of other inter-ring interactions, as will be illustrated in the following section.

For example, the pyridine-2-thiolate ligand (and its derivatives; see ref 4) should on coordination to copper afford the smallest possible four-membered chelate ring. However, the complex that results is $\left[\mathrm{Cu}\left(\mathrm{SC}_{5} \mathrm{H}_{4} \mathrm{~N}\right)\right]_{6}(4){ }^{4}$ which is a hexanuclear aggregate formed by stacking of two trinuclear units. Apparently a four-membered chelate is unfavorable, although one has been reported in $\left[\mathrm{Cu}\left\{\mathrm{SC}(=\mathrm{NPh})\left(\mathrm{OC}_{6} \mathrm{H}_{3} \mathrm{Me}_{2}-2,6\right)\right\}\right.$ $\left.\left(\mathrm{PPh}_{3}\right)_{2}\right]{ }^{32}$ In complex 4, the trinuclear units are held together by coordination of the nitrogen Lewis base from an arenethiolate ligand in the top layer to a copper atom in the bottom layer and vice versa. Actually, when the sulfur atom is bonded to two copper atoms in a two-electron three-center (2e-3c) type of bonding $\left(\mathrm{Cu}-\mathrm{S}-\mathrm{Cu}\right.$ averages $86.6^{\circ}$ in $\left.\left[\mathrm{Cu}_{6}\left(\mathrm{SC}_{5} \mathrm{H}_{4} \mathrm{~N}\right)_{6}\right]^{4 \mathrm{a}}\right)$, the sulfur orbital involved in this bonding would be positioned parallel to the nitrogen lone pair; i.e., chelate formation is highly unlikely because of ring strain, and thus each $\mathrm{SC}_{5} \mathrm{H}_{4} \mathrm{~N}$ anion binds to three copper atoms by S-bridging two copper atoms and N-coordinating a third copper atom (Figure 7). In complex 4, this leads to an arrangement of the copper atoms that resembles an octahedron but lacks precise $O_{h}$ symmetry. For all hexanuclear structures ${ }^{4}$ the description of the aggregate as a combination of two $\mathrm{Cu}_{3} \mathrm{~S}_{3}$ rings held together by coordination of the nitrogen atoms is a possible explanation for the $\mathrm{Cu} \cdots \mathrm{Cu}$ contacts between the top and bottom layers being shorter than the $\mathrm{Cu} \cdots \mathrm{Cu}$ distances within these layers.

Finally, the nonameric aggregate of $\mathbf{6}$ could be described as derived from $\left[\mathrm{Cu}_{6}(\mathrm{SAr})_{6}\right]$ by the uptake of three $\mathrm{Cu}(\mathrm{SAr})$ entities

(32) Abraham, S. P.; Narasimhamurthy, N.; Nethaji, M.; Samuelson, A. G. Inorg. Chem. 1993, 32, 1739-1745.

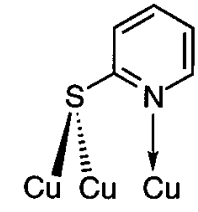

Figure 7. Bonding of the $\mathrm{SC}_{5} \mathrm{H}_{4} \mathrm{~N}$ anion to three $\mathrm{Cu}$ centers in $\left[\mathrm{Cu}_{6}\left(\mathrm{SC}_{5} \mathrm{H}_{4} \mathrm{~N}\right)_{6}\right](4)$.
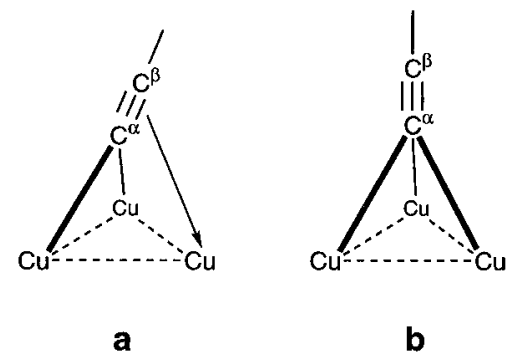

b

Figure 8. Possible bonding descriptions of the alkyne in 9: (a) twoelectron three-center with additional $\eta^{2}$-coordination $(2 \mathrm{e}-3 \mathrm{c}+2 \mathrm{e})$; (b) $\mu_{3}$ two-electron four-center (2e-4c).

between the two layers of the hexanuclear aggregate to form a $[\mathrm{Cu}(\mathrm{SAr})]_{3}$ middle layer in which the $\mathrm{Cu}_{3} \mathrm{~S}_{3}$ ring is rotated $60^{\circ}$ with respect to top and bottom layers. However, a far better description of the geometry of nonameric $\mathbf{6}$ is an aggregate comprising three $\left[\mathrm{Cu}(\mathrm{SAr})_{2}\right]^{-}$anionic cuprate moieties that are held together by three $\left[\mathrm{Cu}_{2}(\mathrm{SAr})\right]^{+}$cationic entities (vide supra).

Going from a $\left[\mathrm{Cu}_{9}(\mathrm{SAr})_{9}\right]$ aggregate, uptake of another three $\mathrm{Cu}(\mathrm{SAr})$ moieties results in the formation of a dodecameric aggregate, as has been observed for $\left[\mathrm{Cu}_{12}\left(\mathrm{SC}_{6} \mathrm{H}_{4} \mathrm{SiMe}_{3}-2\right)_{12}\right]$ (11). ${ }^{5}$ This is clearly not a structure based on a vertical stacking of four $\mathrm{Cu}_{3}(\mathrm{SAr})_{3}$ units but is an expansion of the nonameric framework by addition of three monomeric $\mathrm{Cu}(\mathrm{SAr})$ units at the sulfur atoms in the middle layer. According to the bonding model we propose for $\mathbf{6}$, this dodecameric aggregate could be described as six $\left[\mathrm{Cu}(\mathrm{SAr})_{2}\right]^{-}$anionic cuprate moieties that are held together by six $\mathrm{Cu}^{+}$cations.

Following this trend, the next stable copper(I) arenethiolate aggregate species would be expected to be a $\left[\mathrm{Cu}_{15}(\mathrm{SAr})_{15}\right]$ aggregate which does not have to involve intramolecular coordination but which might be formed if the thiolate possesses suitable bulky substituents.

Mixed Organo(arenethiolato)copper(I) Aggregates. The formation and the structure of alkynyl(arenethiolato)copper(I) aggregate 9 is similar to that of complexes $\left[\mathrm{Cu}_{3}\left\{\mathrm{SC}_{6} \mathrm{H}_{4}-\right.\right.$ $\left.\left.\left(\mathrm{CH}(\mathrm{R}) \mathrm{NMe}_{2}-2\right)\right\}_{2}\left(\mathrm{C} \equiv \mathrm{C}^{t} \mathrm{Bu}\right)\right]_{2}(\mathrm{R}=\mathrm{H}(\mathbf{7 a}), \mathrm{Me}(\mathbf{7 b})),{ }^{11}$ and this is consistent with the earlier observations that $\mathrm{Cu}(\mathrm{SAr})$ aggregates are prone to (intra- and intermolecular) exchange processes. The aggregate 9 is assembled from $\mathrm{Cu}(\mathrm{SAr})$ and $\mathrm{CuC} \equiv \mathrm{C}^{\mathrm{t}} \mathrm{Bu}$ by a yet unknown mechanism, but it is clear that mixed species such as the alkynyl(arenethiolato)copper(I) aggregate 9 must be thermodynamically stable and that the process of (self-)assembling is sensitive as it depends on the structure and electronic features of the single units making the mixed aggregates.

The interaction of the monoanionic $\mathrm{C} \equiv \mathrm{C}^{\mathrm{t}} \mathrm{Bu}$ ligand with the copper atom from the opposite $\mathrm{Cu}_{3} \mathrm{~S}_{2} \mathrm{C}$ unit is a noticeable feature in the structure of $\mathbf{9}$. The alkynyl $\mathrm{C}_{\alpha}$ atom (C1) bridges three copper atoms (Cu1a, $\mathrm{Cu} 2$, and $\mathrm{Cu} 3)$, and at first sight, the acute $\mathrm{Cu} 2-\mathrm{C} 1-\mathrm{Cu} 1 \mathrm{a}$ angle of $77.64(10)^{\circ}$ seems to indicate that the alkyne group is two-electron three-center (2e-3c) bonded to $\mathrm{Cu} 2$ and $\mathrm{Cu} 1 \mathrm{a}$ and that the bonding to $\mathrm{Cu} 3$ is established by additional $\eta^{2}$-coordination (Figure 8a). However, the $\mathrm{Cu} 3-$ $\mathrm{C}_{\beta}$ (alkynyl) distance $(\mathrm{Cu} 3-\mathrm{C} 2)$ of 2.790 (3) $\AA$ as well as the angles $\mathrm{Cu} 2-\mathrm{C} 1-\mathrm{Cu} 3$ and $\mathrm{Cu} 1 \mathrm{a}-\mathrm{C} 1-\mathrm{Cu} 3$ of $74.97(9)$ and 
$80.46(9)^{\circ}$, respectively, are more indicative for a $\mu_{3}$ two-electron four-center $(2 \mathrm{e}-4 \mathrm{c})$ bonding (Figure $8 \mathrm{~b}$ ).

Further support for the $\mu_{3}$-bonding description originates from earlier work in which we have shown that $\eta^{2}$-alkyne-to-copper coordination (Figure 8a) leads not only to a small increase of the $\mathrm{C} \equiv \mathrm{C}$ bond length but more importantly to a significant bending of the alkyne ligand. For example, in monomeric bis$\left(\eta^{2}\right.$-alkyne $)\left(\eta^{1}\right.$-mesityl $)$ - and bis $\left(\eta^{2}\right.$-alkyne $)\left(\eta^{1}\right.$-alkynyl $)$ copper(I) complexes in which the copper atom is trigonally coordinated by two $\eta^{2}$-bonded alkyne ligands and by one $\eta^{1}$-bonded mesityl or alkynyl ligand, the $\mathrm{C} \equiv \mathrm{C}$ bond lengths are 1.250(2) and 1.238 (average) $\AA$ and the $\mathrm{C} \equiv \mathrm{C}-\mathrm{R}$ angles are 155.5(2) and 162.9 (average), respectively. ${ }^{33}$ Furthermore, the $\mathrm{C} \equiv \mathrm{C}$ bond length of the uncoordinated $\eta^{1}$-bonded alkynyl group in the latter complex is $1.215(6) \AA$, while the corresponding $\mathrm{C} \equiv \mathrm{C}-\mathrm{R}$ angle is $177^{\circ} .33$ From a comparison of these data with those for complex 9, where the $\mathrm{C} \equiv \mathrm{C}$ bond length is 1.222(4) $\AA$ and there is an essentially linear $\mathrm{C} \equiv \mathrm{C}^{\mathrm{t}} \mathrm{Bu}$ group $\left(\mathrm{C} 1-\mathrm{C} 2-\mathrm{C} 3179.1(3)^{\circ}\right)$, we conclude that in 9 the $\eta^{2}$-coordination of the alkynyl ligand is absent. Moreover, the distance $\mathrm{Cu} 3-\mathrm{C} 2$ (alkyne- $\mathrm{C}_{\beta}$ ) of 2.790(3) $\AA$ in 9 is extremely long. Thus, although a slipped $\eta^{2}$-coordination of the alkynyl ligand has been proposed for related complexes $\left[\mathrm{Cu}_{3}(\mathrm{SAr})_{2}\left(\mathrm{C} \equiv \mathrm{C}^{\mathrm{t} B u}\right)\right]_{2},{ }^{11}$ we believe that an asymmetric $\mu^{3}-2 \mathrm{e}-4 \mathrm{c}$ bonding description of the alkynyl ligands in 9 (Figure 8b) is more likely. The reason for the observed asymmetry in this bonding is probably of steric origin.

\section{Conclusions}

From the current results and their comparison with those of other copper(I) species, it is apparent that structure of the pure copper(I) arenethiolate aggregates is highly dependent on the arenethiolate organic backbone (chelate size, rigidity of the chelate, Lewis-base strength of the chelating atom, steric bulk), whereas its influence on the structure of mixed organo-

(33) (a) Janssen, M. D.; Herres, M.; Spek, A. L.; Grove, D. M.; Lang, H.; van Koten, G. J. Chem. Soc., Chem. Commun. 1995, 925-926. (b) Janssen, M. D.; Herres, M.; Zsolnai, L.; Grove, D. M.; Spek, A. L.; Lang, H.; van Koten, G. Organometallics 1995, 14, 1098-1100.
(arenethiolato)copper(I) aggregates is less significant. However, the influence that the arenethiolate backbone exerts on the mechanism whereby the latter mixed species are formed has not yet been elucidated, and further studies on this topic using arenethiolate ligands with additional intramolecularly coordinating substituents are ongoing.

The stability of organo(arenethiolato)copper(I) aggregates and their facile and selective formation suggest that these species play an important role in copper arenethiolate catalyzed reactions, and research is current to obtain more information on the structure of cuprates derived from these catalyst species. In this respect, we recently showed that reaction of copper arenethiolates with aryllithium compounds does not always result in the formation of cuprate species $\mathrm{Li}[\mathrm{Cu}(\mathrm{SAr}) \mathrm{R}]$, and this is illustrated by the quantitative isolation ${ }^{34}$ of the pure arylcopper aggregate $\left[\mathrm{Cu}\left(\mathrm{C}_{6} \mathrm{H}_{4} \mathrm{CH}_{2} \mathrm{NMe}_{2}-2\right)\right]_{4}$ from the reaction of $\left[\mathrm{Cu}\left(\mathrm{SC}_{6} \mathrm{H}_{4} \mathrm{NMe}_{2}-2\right)\right]_{3}$ with $\left[\mathrm{Li}\left(\mathrm{C}_{6} \mathrm{H}_{4} \mathrm{CH}_{2} \mathrm{NMe}_{2}-2\right)\right]_{4} \cdot{ }^{13 \mathrm{a}, 34}$ Further characterization of cuprate key intermediates obtained from copper(I) arenethiolate and methyllithium or methylmagnesium iodide by means of EXAFS techniques indicates that indeed mixed organo(arenethiolato)copper(I) aggregates are present in these mixtures. ${ }^{35}$

Acknowledgment. This work was supported in part (A.L.S.) by the Netherlands Foundation for Chemical Research (SON) with financial aid from the Netherlands Organization for Scientific Research (NWO).

Supporting Information Available: Tables of structure determination details, all atomic positional parameters, thermal parameters, bond lengths, and bond angles for $\mathbf{5}, \mathbf{6}$, and $\mathbf{9}$, a PLUTON stick drawing of the asymmetric unit of $\mathbf{6}$, and ORTEP drawings (50\% probability level) of each of the independent nonamers of 6 (54 pages). Ordering information is given on any current masthead page.

\section{IC951664Q}

(34) Janssen, M. D.; Corsten, M. A.; Spek, A. L.; Grove, D. M.; van Koten, G. Organometallics 1996, 15, 2810-2820.

(35) (a) Janssen, M. D.; Mojet, B. L.; van Koten, G.; Koningsberger, D. C. To be published. (b) Janssen, M. D.; van Klaveren, M.; Mojet, B. L.; Grove, D. M.; Koningsberger, D. C.; van Koten, G. To be published. 